\title{
Saudi Arabia: Reports on the Observance of Standards and Codes
}

This paper was prepared based on the information available at the time it was completed in June, 2011. The views expressed in this document are those of the staff team and do not necessarily reflect the views of the government of Saudi Arabia or the Executive Board of the IMF.

The policy of publication of staff reports and other documents by the IMF allows for the deletion of market-sensitive information.

Copies of this report are available to the public from

International Monetary Fund • Publication Services

700 19th Street, N.W. • Washington, D.C. 20431

Telephone: (202) 623-7430 • Telefax: (202) 623-7201

E-mail: publications@imf.org • Internet: http://www.imf.org

\section{International Monetary Fund Washington, D.C.}


FinANCIAL SECTOR ASSESSMENT PROGRAM

\section{SAUDI ARABIA}

\section{The IOSCO OBJeCtIVES AND PRINCIPLES OF SECURITIES}

REGULATION

\section{REPORT ON STANDARDS AND CODES (ROSC)}

JUNE 2011

INTERNATIONAL MONETARY FUND

MONETARY AND CAPITAL MARKETS DEPARTMENT
THE WORLD BANK

FINANCIAL SECTOR VICE PRESIDENCY MidDLE EAST AND NORTH AFRICA REGION

VICE PRESIDENCY 


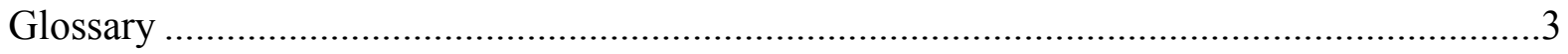

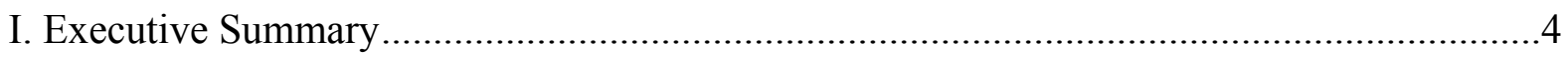

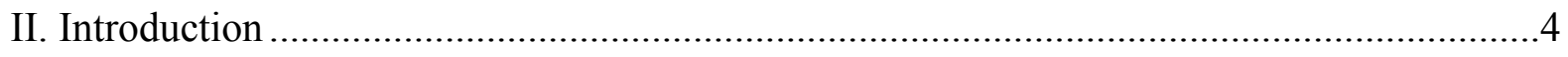

III. Information and Methodology Used for Assessment …..........................................5

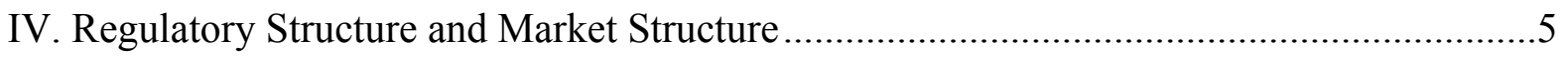

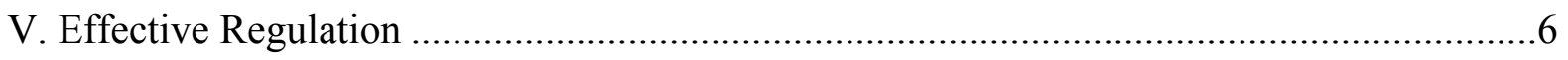

VI. Main Findings of Principle by Principle Assessment .................................................

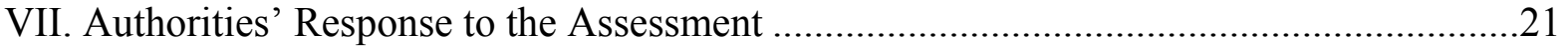

Tables

1. Summary Implementation of the IOSCO Principles ................................................ 10

2. Recommended Action Plan to Improve Implementation of the IOSCO Principles ............18 


\section{GLOSSARY}

$\begin{array}{ll}\text { AP } & \text { Authorized Person } \\ \text { CIF } & \text { Collective Investment Fund } \\ \text { CIS } & \text { Collective Investment Schemes } \\ \text { CMA } & \text { Capital Market Authority } \\ \text { CML } & \text { Capital Market Law } \\ \text { CRSD } & \text { Committee for the Resolution of Securities Disputes } \\ \text { ETF } & \text { Exchange traded fund } \\ \text { IFRS } & \text { International Financial Reporting Standards } \\ \text { IOSCO } & \text { International Organization of Securities Commissions } \\ \text { MMOU } & \text { Multilateral Memorandum of Understanding } \\ \text { MOCI } & \text { Ministry of Commerce and Industry } \\ \text { MOF } & \text { Ministry of Finance } \\ \text { MOU } & \text { Memorandum of understanding } \\ \text { SAMA } & \text { Saudi Arabian Monetary Agency } \\ \text { SOCPA } & \text { Saudi Organization for Certified Public Accountants } \\ \text { SRO } & \text { Self-regulatory organization }\end{array}$




\section{EXECUTIVE SUMMARY}

1. The regulatory framework for the securities market in Saudi Arabia has significantly developed since the enactment of legislation to regulate the capital markets. The Capital Market Authority (CMA) has made significant progress in establishing its supervision credentials, including issuing implementing regulations. The CMA has also entered into information sharing arrangements with other regulators in the region, and is a party to the International Organization of Securities Commissions (IOSCO) Multilateral Memorandum of Understanding (MMOU) Concerning Consultation and Cooperation and the Exchange of Information. However, no information sharing arrangement exists with the Saudi Arabian Monetary Agency (SAMA). Even so, refinements can be made to processes, the Capital Market Law (CML), and the Committee for the Resolution of Securities Disputes (CRSD).

2. There are no major gaps in the current regulatory and legal frameworks. There are some transparency and procedural improvements that need to be made relating to how the CMA funds its operations, disciplines, and communicates with members and balances its potential conflicts of interest.

3. The framework contained in the CML and the implementing regulations is still relatively new. However, revision and updating of the requirements needs to be a continuing program, involving fuller regulated entity participation. Unpublished, but mandatory regulatory instructions issued by the CMA Board to regulated entities need to be publicly available and revised, and Board-imposed disciplinary sanctions need to be overlaid with procedural fairness provisions.

4. The CMA approach to supervision is both risk-based and compliance-focused and the cost of compliance needs to be a more central focus when establishing mandatory obligations.

5. More transparency should be provided by the CMA to cases of noncompliance since Board sanctions of Authorized Persons (APs) may not in all cases be published. The CMA Board should reconsider its current publications policy so as to ensure that the appropriate transparency and regulatory effect is achieved in respect of regulated entities' noncompliance.

\section{INTRODUCTION}

6. The Saudi Arabian capital market has been in operation for many years with substantial trading since 1970. It was regulated by a ministerial committee comprising Ministry of Finance (MOF), Ministry of Commerce and Industry (MOCI), and SAMA, but this changed when the CML came into legal effect on February 25, 2004 and the CMA was established. The CMA was given rule-making authority and enforcement powers necessary to fulfill its objectives (the protection of investors, reduction of systemic risk, and the 
fairness, efficiency, and transparency of the capital market). The CMA possesses both civil and criminal authority and may seek civil sanctions ranging from warnings to monetary penalties, property seizure, and license suspension or revocation. The CML defines the duties and powers of the CMA, Tadawul (the Saudi stock exchange), the Securities Depositary Center, the CRSD (a special body with jurisdiction over all claims and matters falling under the CML and its rules and regulations), and a final review authority, the Appeal Panel.

7. The assessment is part of the Financial Sector Assessment Program Update made at the request of Saudi Arabia, and is the first assessment conducted of the implementation of the IOSCO Objectives and Principles of Securities Regulation. The assessment was undertaken by Mr. Martin Kinsky, a consultant to the IMF for this purpose, and took place in Riyadh during April 2010.

\section{INFORMATION AND METHODOLOGY USED FOR ASSESSMENT}

8. The assessment was conducted based on available public information relevant to the regulatory operations of the CMA, and contained in its regulatory supervisory material, and direct interviews of regulated entities and the staff of the CMA. The assessment was conducted under the 2003 IOSCO assessment methodology.

9. The official language in Saudi Arabia is Arabic. Accordingly, official documents of the CMA are published in Arabic, and most are also available in English. The CMA has endeavored to make its web site fully comprehensive. However, not all mandatory relevant rules and Board directions (Board decisions) are publicly available to participants.

\section{Regulatory Structure And Market Structure}

\section{Regulatory Structure}

10. The CMA's regulatory responsibilities are broad (issuance of securities, listing, trading, and settlement on Tadawul, credit rating agencies, investment funds, disclosure by issuers and governance, licensing, and supervision and enforcement of its regulations). Regulation of banks and insurers is the responsibility of SAMA, except to the extent they have obligations as listed companies in respect of which they fall within the jurisdiction of the CMA.

\section{The CMA's Board of Commissioners comprises five full time members} appointed by Royal Order for a five-year term that is renewable only once. The chief executive officer is the chairman of the Board. Tadawul's Board of Directors comprises nine members appointed by the Council of Ministers and includes representatives of the MOF, MOCI, SAMA, two from listed companies, and four from APs. The Depository is a department of Tadawul. 
12. The CMA is accountable to the President of the Council of Ministers and has access to a number of sources of funds, including fees, financial penalties, and funds provided by the government. Financial accounts of the CMA and Tadawul (wholly owned by the government via an investment company) are not published.

\section{Market Structure}

13. Tadawul operates the only licensed market in Saudi Arabia. It conducts trading in equity securities and debt instruments (including sukuk) of listed companies, corporate bonds and exchange traded funds (ETFs). Tadawul facilitates fully electronic trading in shares (settled $\mathrm{T}+0$ ) and sukuk and bonds (settled two days after trade date ("T+2")), but it does not conduct a derivative market. Trading occurs on a time price priority basis via a central order book. Mutual funds release information publicly via Tadawul, but the funds are not traded on the market. Direct foreign participation in equities is only permitted via swaps entered into with APs, although direct foreign participation is permitted in funds and ETF's. Gulf Cooperation Council residents may also directly trade in the market.

14. At December 31, 2010, there were 97 APs engaged in some combination of regulated securities activities.

15. The CMA reviews and approves a master swap agreement between the $\mathrm{AP}$ and the foreign counter party; but does not approve the clients investing through the swap agreement. The swap effectively immobilizes the securities purchased for the benefit of the foreign interest while providing the economic benefit of the securities to the foreign client. No voting rights may be exercised in respect of such securities.

16. Research is produced on local listed companies, but no credit rating agencies have yet sought to be established in Saudi Arabia.

17. The equity market in Saudi Arabia is of significant size, but has undergone significant change following the establishment of the CMA and the aftermath of the global financial crisis.

\section{EFFECTIVE REgulation}

18. Saudi Arabia is a sharia law jurisdiction which is adopting global standards. For that purpose, the CRSD and the Appeal Committee are special purpose financial services tribunals/courts and, while operating under the CML, are de facto enforcing regulatory provisions which are global and dominated by the common law.

19. Regulation is of a high standard but the market requires further development. Currently, the right to take up a new issue cannot be traded on the market. Derivatives trading, regulated short selling, stock borrowing and lending, and other features of mature markets are absent. The market is predominately comprised of individuals/retail investors. 


\section{Main Findings of Principle by Principle Assessment}

20. The CMA is a relatively new organization that has made substantial progress in establishing the regulatory framework for the capital market in Saudi Arabia. These include the CML, the implementing regulations, the fit-for-future reorganization of the management, and setting the strategy of the agency.

21. Regulatory theory and practice are rapidly changing in response to developments and issues arising around the globe. Accordingly, if the CMA wishes to promote the development of its capital market, which is relatively large in the region, a number of important issues will need to be considered and appropriate regulation introduced, in addition to what has already been completed. In particular, the CMA needs to publicly demonstrate how it manages perceptions of potential conflict of interests/objectives when market development aims and investor protection issues clash.

22. Principles related to the regulator. The CMA is the single entity responsible for administering the primary securities law of Saudi Arabia. A comprehensive and integrated regulatory framework pursuant to the CML and Implementing Regulations is now in place. Under CML, the CMA's objectives, responsibilities, powers and authorities are set out. There is a potential conflict since the CMA is responsible both for regulation and development of the capital market. Corporate governance matters can fall within the authority of both MOCI and the CMA.

23. Principles for self-regulatory organizations (SRO's). There are no SROs, as Tadawul does not exercise regulatory powers, although it is responsible for operationally running the market and the Depository.

24. Principles for enforcement. The CMA has general and broad powers for inspection and investigation and it conducts full electronic surveillance of the market. The CMA has a dedicated enforcement division, but the track record of the CMA on enforcement is not fully transparent. The CMA has the authority to investigate potential violations and to bring enforcement action seeking civil and criminal penalties. It may suspend or withdraw the license of an AP who deliberately violates the CML or its implementing regulations. An inspection program adopting a cycle of two to three years of APs (risk and compliancebased) is conducted via onsite inspections and review of specific regulations.

25. Principles for cooperation. The CMA has the power to share information with domestic and foreign regulators, is a full signatory to the IOSCO MMOU, and is a member of the Union of Arab Securities Authorities (a cooperative body which inter alia, shares information). To date, no release of confidential regulatory information has been required, although the CMA is willing to do so if requested. 
26. Principles for issuers. Issuers that offer securities by way of public offer are subject to disclosure requirements, including shareholder voting decisions and provisions for equality of treatment. Prospectuses are approved by the CMA. Reporting and disclosure by significant shareholders of listed companies and by persons who would seek control of a listed company are also required. Minimum information requirements for prospectuses (debt and equity securities) require that the prospectus contain sufficient information to enable an investor to assess the issuer's activities, financial position, management, and prospects, as well as the rights and obligations attaching to the securities. A prospectus must include three years' operating financial results. Private placement activity is low.

27. Principles for collective investment schemes (CIS). Only a person authorized by the CMA to engage in "managing business" may operate and market a CIS, and must demonstrate compliance with criteria relating to honesty and integrity, adequacy of resources, financial capacity, internal management procedures, and systems. The manager is required to disclose sufficient information about the fund's management, objectives, strategies, risks, and other information to enable potential investors to make an informed investment decision. A person seeking to offer units in an investment or real estate fund (fund types permitted) by way of a public offer must obtain the CMA approval. Investment funds may also be offered by way of a private placement to certain classes of sophisticated investors. Foreign investment funds may not be offered within Saudi Arabia without the CMA consent. The CMA regulations prescribing the legal form and structure of funds have not been tested, as no judicial upholding of the protection of clients' rights in such schemes has occurred. When a manager applies for approval to offer and sell units in a fund, the CMA reviews the valuation method to ensure that it is fair and reliable. Fund managers must calculate asset valuations on a regular basis. Valuation of the assets of an investment fund must occur on each of at least two dealing days each week when units of the fund are sold and redeemed. Valuation of the assets of a real estate investment fund must occur at least once every six months.

28. Principles for market intermediaries. Market intermediaries require an AP license, depending on business category. The CMA will review an applicant's business plan, manuals, policies and procedures, and audited financial statements, including the skills, experience, competence, and integrity of its employees, officers, and agents, certain of whom must be registered and pass a qualification examination. Minimum paid up capital and net capital requirements based on risk (see Principle 22) apply for each security business category. Dealing, custody, and managing requires paid capital of SR 50 million, but arranging is SR 2 million, and advising requires SR 400,000. The CMA monitors APs' compliance with its capital adequacy and other obligations, but it has no specific or documented process or plan to assist it to deal with an unexpected failure of an AP.

29. Principles for secondary markets. By law, the only securities exchange authorized is Tadawul, which the CMA must oversee as a securities exchange and depository. The CMA must approve all rules and rule changes of Tadawul. The CML does not allow for the 
establishment of a new securities exchange, nor of a trading system. No rules, procedures, or guidance have been issued to set out how the CMA would deal with the regulatory oversight to apply to an alternative trading system or new exchange. Dealing may occur away from the market in limited circumstances as private transactions, but over the counter activity would therefore appear to be low. 
Table 1. Saudi Arabia: Summary Implementation of the IOSCO Principles

\begin{tabular}{|c|c|}
\hline Principle & Findings \\
\hline $\begin{array}{l}\text { Principle } 1 . \text { The responsibilities of the regulator should be } \\
\text { clearly and objectively stated. }\end{array}$ & $\begin{array}{l}\text { The CMA is the single entity responsible for administering } \\
\text { the CML, which clearly defines the CMA's objectives, } \\
\text { responsibilities, powers and authorities. The CMA has used } \\
\text { its authority to establish a comprehensive and integrated } \\
\text { regulatory framework by issuing (and updating) } \\
\text { implementing regulations. There is no reference in the CML } \\
\text { to the division of responsibility that occurs in practice } \\
\text { between the CMA, MOCI, and other government entities } \\
\text { relating to the responsibilities of these regulators for } \\
\text { corporations that operate in the capital market. Accounting } \\
\text { and auditing standards are established by the Saudi } \\
\text { Organization for Certified Public Accountants (SOCPA), a } \\
\text { professional organization that operates under the supervision } \\
\text { of MOCI. Company incorporation, management, and } \\
\text { general assembly meetings are regulated by the companies' } \\
\text { law which is the responsibility of MOCI and not the CMA. } \\
\text { Capital increases and decreases of joint stock companies fall } \\
\text { under the jurisdiction of both the CMA and MOCI. Each has } \\
\text { different responsibilities for these matters as set out in the } \\
\text { memorandum of understanding (MOU), available only in an } \\
\text { Arabic version. A gray area relating to the corporate } \\
\text { governance matters which could fall within the authority of } \\
\text { both MOCI and the CMA exists. There also is a potential } \\
\text { conflict, since the CMA is responsible both for regulation } \\
\text { and development of the capital market. }\end{array}$ \\
\hline $\begin{array}{l}\text { Principle } 2 . \text { The regulator should be operationally } \\
\text { independent and accountable in the exercise of its } \\
\text { functions and powers. }\end{array}$ & $\begin{array}{l}\text { The CML establishes the CMA as a legal entity to be a } \\
\text { financially and administratively autonomous agency, } \\
\text { invested with all authorities necessary to discharge its } \\
\text { responsibilities and functions. The CMA is governed by a } \\
\text { Board comprising five full time members, who are each } \\
\text { appointed by Royal Order for a five-year term that is } \\
\text { renewable once. There is no express statutory protection for } \\
\text { the CMA that would give it immunity from suit where it } \\
\text { discharges its powers and responsibilities under the CML or } \\
\text { implementing regulations. The CMA retains fees and fines } \\
\text { as a revenue source (subject to the general reserve cap); } \\
\text { however, the quantum of fines is not published, although } \\
\text { some individual disciplinary fines have been published. } \\
\text { Members of the CRSD are appointed by the Board (for } \\
\text { three-year term, renewable), however. The CSRD is given } \\
\text { exclusive jurisdiction to review the CMA decisions. There } \\
\text { are no statutory provisions or limitations on the } \\
\text { circumstances for which a Board or CRSD member may be } \\
\text { removed. } \\
\text { The CMA Board has determined a publications policy } \\
\text { which specifies the matters which must be announced to the } \\
\text { public, but not all regulatory decisions are public. }\end{array}$ \\
\hline $\begin{array}{l}\text { Principle } 3 \text {. The regulator should have adequate powers, } \\
\text { proper resources, and the capacity to perform its functions } \\
\text { and exercise its powers. }\end{array}$ & $\begin{array}{l}\text { The CML grants the CMA all powers and authorities to } \\
\text { carry out its functions, which include issuing implementing } \\
\text { regulations, conducting inquiries and investigations }\end{array}$ \\
\hline
\end{tabular}




\begin{tabular}{|c|c|}
\hline Principle & Findings \\
\hline & $\begin{array}{l}\text { regarding violations, defining and explaining the terms and } \\
\text { provisions set out in the CML, and performing incidental } \\
\text { responsibilities. The powers and authorities are broad. Staff } \\
\text { numbers are considerable and the division/department sizes } \\
\text { appear to be adequate. }\end{array}$ \\
\hline $\begin{array}{l}\text { Principle } 4 . \text { The regulator should adopt clear and } \\
\text { consistent regulatory processes. }\end{array}$ & $\begin{array}{l}\text { The CMA advises regulated entities of Board resolutions } \\
\text { which contain substantive compliance requirements. Some } \\
\text { will not involve prior consultation and may not be public, } \\
\text { although they will be circulated to the entities directly } \\
\text { affected once the content becomes mandatory. } \\
\text { The CMA states that it considers the cost of compliance } \\
\text { when it formulates new or amended regulations and by } \\
\text { virtue of the consultation process, although it has not } \\
\text { published any statement explaining how it does so. } \\
\text { The CMA is a relatively new organization (staff } \\
\text { reorganization/recruitment has recently taken place) and it is } \\
\text { adopting new/upgraded rules. Some regulated entities are } \\
\text { not fully aware of the ambit of their responsibilities. There } \\
\text { can be areas of ambiguity about the interpretation of } \\
\text { obligations which may not become apparent until an } \\
\text { inspection visit, when the CMA staff advise their } \\
\text { interpretation of them. The CMA's policy seems to be to } \\
\text { educate participants via the supervision/inspection process, } \\
\text { often by way of the CMA Board imposed fines; although it } \\
\text { also adopts other means to educate participants, including } \\
\text { publications. } \\
\text { While there is no express right to be heard prior to a } \\
\text { decision on an application being rejected, all adverse } \\
\text { decisions of the CMA are appealable to the CRSD, which } \\
\text { will investigate the claim and issue a reasoned decision, and } \\
\text { adverse actions may be further appealed to the Appeal } \\
\text { Panel. }\end{array}$ \\
\hline $\begin{array}{l}\text { Principle } 5 \text {. The staff of the regulator should observe the } \\
\text { highest professional standards. }\end{array}$ & $\begin{array}{l}\text { The CML establishes standards of conduct designed to } \\
\text { ensure the integrity and professionalism of the staff. The } \\
\text { CMA Board and its employees are prohibited from engaging } \\
\text { in any other job or profession and from providing advice to } \\
\text { any company or private institution. The CMA staff must } \\
\text { disclose their securities holdings and the securities holdings } \\
\text { of their relatives. } \\
\text { The CMA has adopted a Code of Conduct that incorporates } \\
\text { relevant provisions of the CML and establishes additional } \\
\text { prohibitions and requirements designed to avoid conflicts of } \\
\text { interest, protect confidentiality and personal information, } \\
\text { and ensure the appropriate use of information. }\end{array}$ \\
\hline $\begin{array}{l}\text { Principle } 6 . \text { The regulatory regime should make } \\
\text { appropriate use of SROs that exercise some direct } \\
\text { oversight responsibility for their respective areas of } \\
\text { competence and to the extent appropriate to the size and } \\
\text { complexity of the markets. }\end{array}$ & $\begin{array}{l}\text { Tadawul is not an SRO and does not exercise regulatory } \\
\text { powers, although it is responsible for operating the market } \\
\text { and the Depository. The future development of Tadawul } \\
\text { may envisage it achieving a self-listing with direct public } \\
\text { participation in its ownership. }\end{array}$ \\
\hline Principle 7. SROs should be subject to the oversight of the & Tadawul does not exercise such powers nor does it have \\
\hline
\end{tabular}




\begin{tabular}{|c|c|}
\hline Principle & Findings \\
\hline $\begin{array}{l}\text { regulator and should observe standards of fairness and } \\
\text { confidentiality when exercising powers and delegated } \\
\text { responsibilities. }\end{array}$ & $\begin{array}{l}\text { delegated responsibility. See also comments above at } \\
\text { Principle } 6 .\end{array}$ \\
\hline $\begin{array}{l}\text { Principle } 8 \text {. The regulator should have comprehensive } \\
\text { inspection, investigation, and surveillance powers. }\end{array}$ & $\begin{array}{l}\text { The CMA has general and broad powers for inspection and } \\
\text { investigation, including nonlicensees. It conducts full } \\
\text { electronic surveillance of the market and has access to } \\
\text { changes in beneficial ownership. There is a dedicated } \\
\text { enforcement division, but the track record of the CMA on } \\
\text { enforcement is not fully transparent due to the publications } \\
\text { policy of its Board. }\end{array}$ \\
\hline $\begin{array}{l}\text { Principle } 9 . \text { The regulator should have comprehensive } \\
\text { enforcement powers. }\end{array}$ & $\begin{array}{l}\text { The CMA has authority to investigate potential violations } \\
\text { and to bring enforcement actions seeking civil and criminal } \\
\text { penalties. } \\
\text { The CMA also may seek indemnification for persons } \\
\text { harmed by the violation or require the violator to disgorge } \\
\text { any gain realized from the violation. } \\
\text { The Board may suspend or withdraw the license of an AP. } \\
\text { The maximum fines stipulated in the CML for any violation } \\
\text { of the law, regulations or rules are not high, and for } \\
\text { individual breaches may not be sufficient to provide an } \\
\text { effective deterrent for such violations. }\end{array}$ \\
\hline $\begin{array}{l}\text { Principle } 10 \text {. The regulatory system should ensure an } \\
\text { effective and credible use of inspection, investigation, } \\
\text { surveillance, and enforcement powers and implementation } \\
\text { of an effective compliance program. }\end{array}$ & $\begin{array}{l}\text { The CMA implements an inspection program of APs by } \\
\text { carrying out onsite inspections and review of specific } \\
\text { regulations. A cycle of two to three years for inspections has } \\
\text { been adopted (unless an issue arises). The inspection } \\
\text { program is risk and compliance based. } \\
\text { Not all enforcement actions (and agreed settlements of } \\
\text { action) are published. The CMA's publication policy is } \\
\text { underpinned by concern that disciplinary outcomes, } \\
\text { specifically the announcement of sanctions against APs, } \\
\text { may affect the development of the local market by adversely } \\
\text { affecting investor confidence in the market and investors' } \\
\text { willingness to continue to conduct business with the entity } \\
\text { were its name and details of its violations to be made public. }\end{array}$ \\
\hline $\begin{array}{l}\text { Principle } 11 . \text { The regulator should have the authority to } \\
\text { share both public and nonpublic information with } \\
\text { domestic and foreign counterparts. }\end{array}$ & $\begin{array}{l}\text { The CMA may share regulatory information with other } \\
\text { regulators. This includes records identifying the beneficial } \\
\text { owners or controllers of bank accounts relating to securities } \\
\text { transactions and information from issuers. }\end{array}$ \\
\hline $\begin{array}{l}\text { Principle } 12 \text {. Regulators should establish information- } \\
\text { sharing mechanisms that set out when and how they will } \\
\text { share both public and nonpublic information with their } \\
\text { domestic and foreign counterparts. }\end{array}$ & $\begin{array}{l}\text { The CMA is a member of the Union of Arab Securities } \\
\text { Authorities and a full signatory to the IOSCO MMOU } \\
\text { Concerning Consultation and Cooperation and the Exchange } \\
\text { of Information. } \\
\text { There has been cooperation domestically and the CMA has } \\
\text { MOUs with MOCI (securities and related companies law } \\
\text { matters), Minister of the Interior (anti-money laundering and } \\
\text { combating the financing of terrorism), and Minister of } \\
\text { Justice (real estate funds' ownership of assets). However, } \\
\text { the CMA has not yet finalized an MOU with SAMA; one is } \\
\text { currently being drafted. }\end{array}$ \\
\hline
\end{tabular}




\begin{tabular}{|c|c|}
\hline Principle & Findings \\
\hline $\begin{array}{l}\text { Principle } 13 . \text { The regulatory system should allow for } \\
\text { assistance to be provided to foreign regulators who need } \\
\text { to make inquiries in the discharge of their functions and } \\
\text { exercise of their powers. }\end{array}$ & $\begin{array}{l}\text { The CMA's powers under the CML enable it to provide } \\
\text { assistance to a foreign regulator by investigating an alleged } \\
\text { breach of a legal or regulatory requirement or providing } \\
\text { such other assistance as the CMA may deem appropriate. } \\
\text { The CMA interprets this authority broadly. }\end{array}$ \\
\hline $\begin{array}{l}\text { Principle 14. There should be full, timely, and accurate } \\
\text { disclosure of financial results and other information that is } \\
\text { material to investors' decisions. }\end{array}$ & $\begin{array}{l}\text { Disclosure by issuers (listed companies) and relating to } \\
\text { Collective Investment Funds (CIF) that offer securities by } \\
\text { way of public offer are subject to specific and general } \\
\text { disclosure requirements that apply both to the prospectus } \\
\text { used for a securities offering and on a continuing basis } \\
\text { thereafter, including shareholder voting decisions. Reporting } \\
\text { and disclosure by significant shareholders of listed } \\
\text { companies and by persons who would seek control of a } \\
\text { listed company are also required. } \\
\text { Minimum information requirements for prospectuses (debt } \\
\text { and equity securities) require that the prospectus contain } \\
\text { sufficient information to enable an investor to assess the } \\
\text { issuer's activities, financial position, management and } \\
\text { prospects as well as the rights and obligations attaching to } \\
\text { the securities. A prospectus must include three years' } \\
\text { operating financial results (audited accounts must have been } \\
\text { published for at least the previous three years) and } \\
\text { comparative financial information of the company for the } \\
\text { previous two years, unless exempted. }\end{array}$ \\
\hline $\begin{array}{l}\text { Principle } 15 . \text { Holders of securities in a company should be } \\
\text { treated in a fair and equitable manner. }\end{array}$ & $\begin{array}{l}\text { There are a numerous provisions governing shareholders' } \\
\text { rights, including takeover regulations. A person who } \\
\text { becomes owner of or interested in } 5 \text { percent or more of any } \\
\text { class of voting securities or convertible debt securities of a } \\
\text { listed company is published, as are increases or decreases by } \\
1 \text { percent or more. } \\
\text { The regulation of corporate governance for listed companies } \\
\text { takes a bifurcated approach. There is some overlap } \\
\text { regarding the obligations imposed by the CMA and MOCI. } \\
\text { It is unclear how they would be enforced in the event of a } \\
\text { major case of a listed company's failure to comply with } \\
\text { these corporate governance obligations, which involve } \\
\text { serious breaches of directors' duties. }\end{array}$ \\
\hline $\begin{array}{l}\text { Principle 16. Accounting and auditing standards should be } \\
\text { of a high and internationally acceptable quality. }\end{array}$ & $\begin{array}{l}\text { Financial statements relating to CIF and of listed companies } \\
\text { disclosed in offering documents and on a continuing basis } \\
\text { are subject to accounting and auditing standards established } \\
\text { by SOCPA, a professional organization that operates under } \\
\text { the supervision of the MOCI. Since IOSCO does not } \\
\text { provide criteria for assessment of whether or not these } \\
\text { standards are comprehensive and of internationally accepted } \\
\text { quality, the assessor has noted the CMA's view that it } \\
\text { considers SOCPA standards to be of international quality, } \\
\text { and that there are differences in the treatment of certain } \\
\text { issues, such as valuation of real property, from that under } \\
\text { International Financial Reporting Standards (IFRS). } \\
\text { SAMA requires insurance companies and banks to comply } \\
\text { with IFRS. The CMA Board has issued a resolution that }\end{array}$ \\
\hline
\end{tabular}




\begin{tabular}{|c|c|}
\hline Principle & Findings \\
\hline & $\begin{array}{l}\text { exempts listed banks and insurance companies from } \\
\text { preparing their interim and annual accounts in accordance } \\
\text { with SOCPA standards as mandated under the listing rules } \\
\text { and to use, alternatively, IFRS standards. }\end{array}$ \\
\hline $\begin{array}{l}\text { Principle } 17 . \text { The regulatory system should set standards } \\
\text { for the eligibility and the regulation of those who wish to } \\
\text { market or operate a collective investment scheme. }\end{array}$ & $\begin{array}{l}\text { Only a person authorized by the CMA to engage in } \\
\text { "managing business" may operate and market a collective } \\
\text { investment scheme. Applicants must demonstrate } \\
\text { compliance with set criteria prior to being authorized, } \\
\text { including those of being fit and proper, and having sufficient } \\
\text { capacity and appropriate internal control systems. } \\
\text { The regulations distinguish between investment funds and } \\
\text { real estate investment funds. A person seeking authority to } \\
\text { offer units in either type of fund by way of a public offer } \\
\text { must obtain the CMA approval. An investment fund } \\
\text { established in a jurisdiction other than Saudi Arabia may not } \\
\text { be offered within Saudi Arabia without the CMA consent. } \\
\text { Funds and their managers are subject to ongoing supervision } \\
\text { via inspections and reporting requirements to ensure } \\
\text { continued compliance with requirements. }\end{array}$ \\
\hline $\begin{array}{l}\text { Principle } 18 \text {. The regulatory system should provide for } \\
\text { rules governing the legal form and structure of collective } \\
\text { investment schemes and the segregation and protection of } \\
\text { client assets. }\end{array}$ & $\begin{array}{l}\text { The CMA regulations prescribe the legal form and structure } \\
\text { of funds. Investment funds and real estate funds are } \\
\text { established by a signed contract between the fund manager } \\
\text { and fund investors, which must contain terms and conditions } \\
\text { prescribed by the CMA regulations. } \\
\text { The manager of a fund or an affiliate may hold fund assets } \\
\text { but must segregate these assets from any other assets. } \\
\text { The CMA's filing and approval process is designed to } \\
\text { ensure compliance with applicable form and structure } \\
\text { requirements, but there has been no judicial upholding of the } \\
\text { protection of clients' rights in such schemes. }\end{array}$ \\
\hline $\begin{array}{l}\text { Principle 19. Regulation should require disclosure, as set } \\
\text { out under the principles for issuers, which is necessary to } \\
\text { evaluate the suitability of a collective investment scheme } \\
\text { for a particular investor and the value of the investor's } \\
\text { interest in the scheme. }\end{array}$ & $\begin{array}{l}\text { The manager of a fund is required to disclose sufficient } \\
\text { information about the fund's management, objectives, } \\
\text { strategies, risks, and other information to enable potential } \\
\text { investors to make an informed investment decision. } \\
\text { The CMA approves the terms and conditions of the } \\
\text { investment. } \\
\text { Managers of funds must make available to fund investors } \\
\text { annual audited and interim financial statements that are } \\
\text { prepared according to standards issued by SOCPA. }\end{array}$ \\
\hline $\begin{array}{l}\text { Principle 20. Regulation should ensure that there is a } \\
\text { proper and disclosed basis for assets valuation and the } \\
\text { pricing and the redemption of units in a collective } \\
\text { investment scheme. }\end{array}$ & $\begin{array}{l}\text { The terms and conditions of funds must describe the method } \\
\text { of valuing the assets of the fund, the timing of the valuation, } \\
\text { and the method of publishing the price of its units. } \\
\text { Valuations must be conducted in accordance with SOCPA } \\
\text { standards. The CMA reviews the valuation method to ensure } \\
\text { that it is fair and reliable. } \\
\text { Fund managers must calculate asset valuations on a regular } \\
\text { basis. Valuation of the assets of an investment fund must } \\
\text { occur on each of at least two dealing days each week when } \\
\text { units of the fund are sold and redeemed. Valuation of the } \\
\text { assets of a real estate investment fund must occur at least }\end{array}$ \\
\hline
\end{tabular}




\begin{tabular}{|c|c|}
\hline Principle & Findings \\
\hline & $\begin{array}{l}\text { once every six months. } \\
\text { Requirements addressing pricing errors and specific } \\
\text { authority to require notification and to take action with } \\
\text { respect to the suspension or deferral of redemption rights are } \\
\text { under consideration. }\end{array}$ \\
\hline $\begin{array}{l}\text { Principle } 21 . \text { Regulation should provide for minimum } \\
\text { entry standards for market intermediaries. }\end{array}$ & $\begin{array}{l}\text { The CMA assesses the applicant for an AP license by } \\
\text { reviewing its business plan, manuals, policies and } \\
\text { procedures, and audited financial statements. In considering } \\
\text { whether an applicant is fit and proper, the skills, experience, } \\
\text { competence, and integrity of its employees, officers, and } \\
\text { agents are assessed. } \\
\text { The CMA also prescribes minimum paid up capital } \\
\text { requirements for each security business category and } \\
\text { minimum net capital requirements. } \\
\text { Applicants must list each individual who is to be a } \\
\text { "registered person" and details of their qualifications and } \\
\text { experience. Applicants for registration must pass a } \\
\text { qualification examination required by the CMA, or secure } \\
\text { an exemption. }\end{array}$ \\
\hline $\begin{array}{l}\text { Principle } 22 \text {. There should be initial and ongoing capital } \\
\text { and other prudential requirements for market } \\
\text { intermediaries that reflect the risks that the intermediaries } \\
\text { undertake. }\end{array}$ & $\begin{array}{l}\text { APs are required to comply with initial and ongoing capital } \\
\text { requirements, details of which are set out in a Prudential } \\
\text { Guidance Note. The initial requirement of paid capital must } \\
\text { be not less than the following: dealing, custody, and } \\
\text { managing, SR } 50 \text { million; arranging, SR } 2 \text { million; and } \\
\text { advising, SR 400,000. On an ongoing basis APs which carry } \\
\text { on dealing, managing, or custody must comply with a net } \\
\text { capital standard of the greatest of SR } 50 \text { million, } 5 \text { percent } \\
\text { of the AP's annual revenue, or an amount calculated based } \\
\text { on aggregate indebtedness. These requirements are designed } \\
\text { to ensure that dealers, mangers, and custodians must } \\
\text { maintain more capital as risks increase. Requirements } \\
\text { applicable to margin lending specify the circumstances } \\
\text { under which AP may effect a margin transaction for a client. } \\
\text { However, margin lending is primarily undertaken though } \\
\text { banks. APs are required to self-report if net capital falls } \\
\text { below the minimum, and the CMA monitors the monthly } \\
\text { capital adequacy returns submitted by them. }\end{array}$ \\
\hline $\begin{array}{l}\text { Principle } 23 \text {. Market intermediaries should be required to } \\
\text { comply with standards for internal organization and } \\
\text { operational conduct that aim to protect the interests of } \\
\text { clients, ensure proper management of risk, and under } \\
\text { which management of the intermediary accepts primary } \\
\text { responsibility for these matters. }\end{array}$ & $\begin{array}{l}\text { APs must establish and maintain a division of } \\
\text { responsibilities among directors and senior management, } \\
\text { and written risk management policies, compliance } \\
\text { procedures, compliance monitoring programs, operating } \\
\text { procedures, and an employee code of conduct. There must } \\
\text { be a compliance officer and a money laundering reporting } \\
\text { officer. } \\
\text { The governing body of the AP must carry out and document } \\
\text { a regular review of its internal controls and risk } \\
\text { management program. } \\
\text { An AP's internal and external auditors must review its } \\
\text { books, accounts, and other records at least annually. The } \\
\text { internal auditor is responsible for appraising risk } \\
\text { management strategies and internal controls. }\end{array}$ \\
\hline
\end{tabular}




\begin{tabular}{|c|c|}
\hline Principle & Findings \\
\hline & $\begin{array}{l}\text { An AP must establish written procedures to ensure the } \\
\text { timely resolution of client complaints. }\end{array}$ \\
\hline $\begin{array}{l}\text { Principle } 24 \text {. There should be a procedure for dealing with } \\
\text { the failure of a market intermediary in order to minimize } \\
\text { damage and loss to investors and to contain systemic risk. }\end{array}$ & $\begin{array}{l}\text { The CMA monitors APs' compliance with its capital } \\
\text { adequacy and other obligations. The CMA has extensive } \\
\text { power to represent and protect the rights of clients to their } \\
\text { funds and assets and supervise the compulsory or voluntary } \\
\text { liquidation of an AP's business. However, the CMA has no } \\
\text { specific or documented process or plan to assist it to deal } \\
\text { with an unexpected failure of an AP. It is unclear how the } \\
\text { CMA would deal with an AP's failure/insolvency, } \\
\text { particularly if other regulatory agencies are involved. }\end{array}$ \\
\hline $\begin{array}{l}\text { Principle } 25 \text {. The establishment of trading systems } \\
\text { including securities exchanges should be subject to } \\
\text { regulatory authorization and oversight. }\end{array}$ & $\begin{array}{l}\text { The only securities exchange authorized under the CML in } \\
\text { Saudi Arabia is Tadawul, and the CMA has full } \\
\text { responsibility and authority to oversee Tadawul in its } \\
\text { capacity both as a securities exchange and depository. The } \\
\text { CML does not allow for the establishment of a new } \\
\text { securities exchange or of a trading system. } \\
\text { No rules, procedures, or guidance have been issued to set } \\
\text { out how the CMA would deal with an alternative exchange } \\
\text { or trading system. } \\
\text { The CMA believes that there will never be an alternative } \\
\text { trading system or new exchange. }\end{array}$ \\
\hline $\begin{array}{l}\text { Principle } 26 . \text { There should be ongoing regulatory } \\
\text { supervision of exchanges and trading systems, which } \\
\text { should aim to ensure that the integrity of trading is } \\
\text { maintained through fair and equitable rules that strike an } \\
\text { appropriate balance between the demands of different } \\
\text { market participants. }\end{array}$ & $\begin{array}{l}\text { The CMA is required to regulate and develop the Tadawul, } \\
\text { seek to develop and improve methods of systems and } \\
\text { entities trading in securities, develop procedures that would } \\
\text { reduce the risks related to securities transactions, and seek to } \\
\text { achieve fairness, efficiency, and transparency in securities } \\
\text { transactions. The CMA conducts ongoing regulatory } \\
\text { supervision of Tadawul. } \\
\text { The CML also authorizes Tadawul to adopt rules, subject to } \\
\text { approval by the CMA, to govern its operations and, among } \\
\text { other things, ensure fairness, efficiency, and transparency in } \\
\text { the exchange's affairs. }\end{array}$ \\
\hline $\begin{array}{l}\text { Principle 27. Regulation should promote transparency of } \\
\text { trading. }\end{array}$ & $\begin{array}{l}\text { Tadawul has adopted trading instructions governing the } \\
\text { disclosure of information about any transactions on the } \\
\text { market or affecting the Depository. } \\
\text { The electronic trading system continuously disseminates to } \\
\text { Tadawul members in real-time (as well as to information } \\
\text { vendors and others with licensing agreements with } \\
\text { Tadawul) the } 10 \text { best bid and } 10 \text { best ask limits in the order } \\
\text { book for each tradable listed security, including the number } \\
\text { of orders and total disclosed order quantity at each price } \\
\text { limit. Market information and trading data is publicly } \\
\text { available free after a } 5 \text { minute delay. }\end{array}$ \\
\hline $\begin{array}{l}\text { Principle 28. Regulation should be designed to detect and } \\
\text { deter manipulation and other unfair trading practices. }\end{array}$ & $\begin{array}{l}\text { CML and provisions of the Market Conduct Regulations } \\
\text { prohibit market manipulation, the dissemination of } \\
\text { misleading information, insider trading, front running, and } \\
\text { other fraudulent or deceptive conduct. } \\
\text { The CMA also has included disclosure requirements in the } \\
\text { listing rules, in order to seek to ensure that material }\end{array}$ \\
\hline
\end{tabular}




\begin{tabular}{|l|l|}
\hline \multicolumn{1}{|c|}{ Principle } & \multicolumn{1}{c|}{ Findings } \\
\hline & $\begin{array}{l}\text { information is not omitted from prospectuses and company } \\
\text { announcements on which investors rely. } \\
\text { The CMA ensures compliance with these provisions using a } \\
\text { combination of surveillance of market activity, inspections, } \\
\text { and reporting, and takes enforcement action where breaches } \\
\text { are found. }\end{array}$ \\
$\begin{array}{l}\text { Principle 29. Regulation should aim to ensure the proper } \\
\text { management of large exposures, default risk and market } \\
\text { disruption. }\end{array}$ & $\begin{array}{l}\text { Securities market open positions and credit exposures are } \\
\text { limited to the credit extended and guaranteed to an AP and } \\
\text { its customers by a clearing bank. The clearing banks are } \\
\text { supervised by SAMA. Before allowing entry of an order } \\
\text { into the order book the electronic trading system } \\
\text { automatically checks to ensure that execution of that order } \\
\text { will not cause the AP to exceed its daily and intra-day credit } \\
\text { limit set by its clearing bank. Any order that would cause an } \\
\text { AP to exceed its credit limit is rejected by the electronic } \\
\text { trading system. }\end{array}$ \\
\hline $\begin{array}{l}\text { Principle 30. Systems for clearing and settlement of } \\
\text { securities transactions should be subject to regulatory } \\
\text { oversight and designed to ensure that they are fair, } \\
\text { effective, and efficient and that they reduce systemic risk. }\end{array}$ & $\begin{array}{l}\text { Not assessed. } \\
\end{array}$ \\
\hline
\end{tabular}




\section{Table 2. Saudi Arabia: Recommended Action Plan to Improve Implementation of the IOSCO Principles}

\begin{tabular}{|c|c|}
\hline Principle & Recommended Action \\
\hline $\begin{array}{l}\text { Principles Relating to the Regulator } \\
\text { (Principles 1-5) }\end{array}$ & 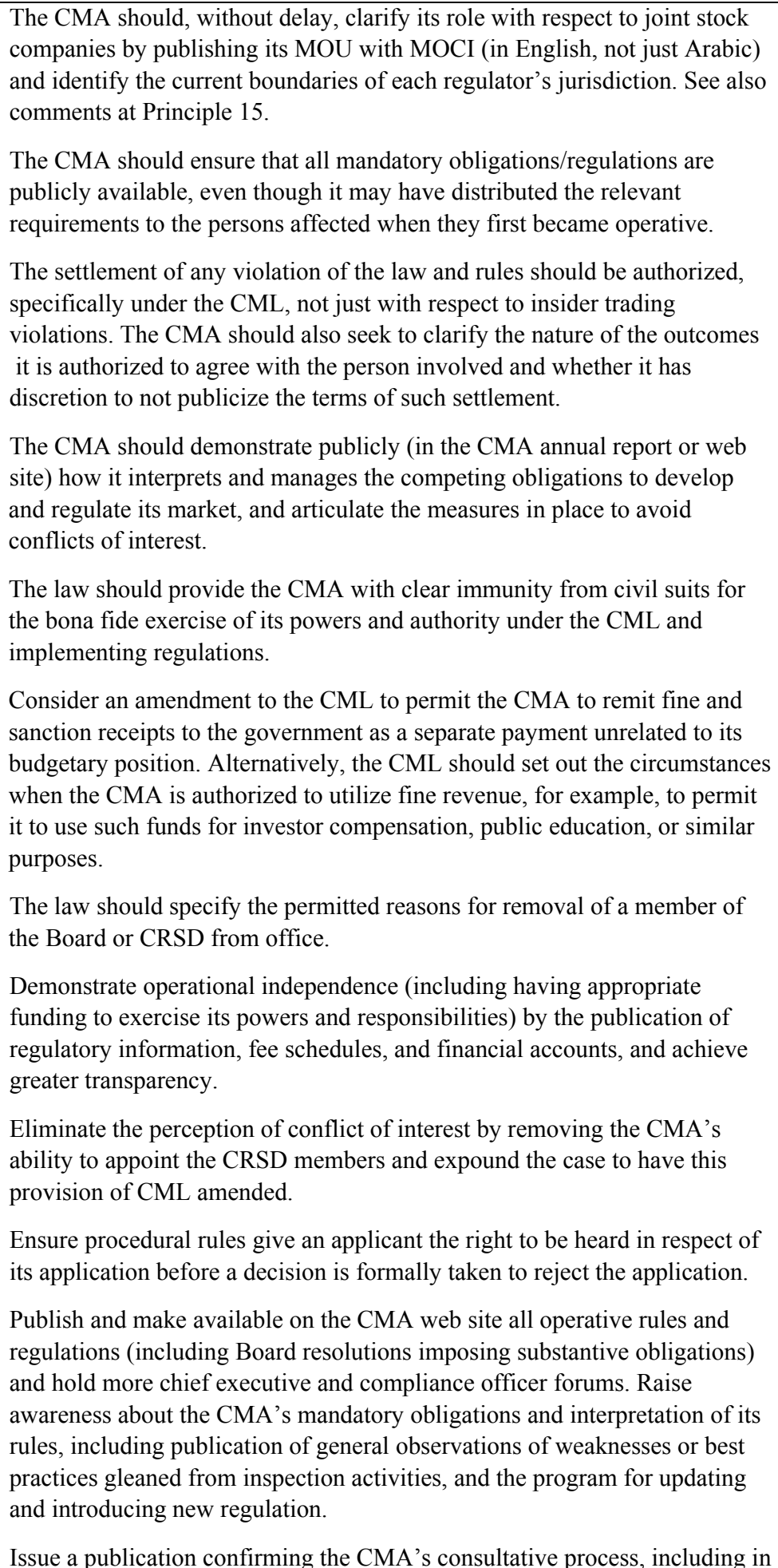 \\
\hline
\end{tabular}




\begin{tabular}{|c|c|}
\hline Principle & Recommended Action \\
\hline & $\begin{array}{l}\text { detail its agenda for regulatory change and how it balances the costs of } \\
\text { compliance in setting new rules. } \\
\text { Publish Guidance Notes, setting out how the CMA interprets regulatory } \\
\text { obligations applicable to APs. } \\
\text { Seek to have the CML amended to set out the required procedural fairness } \\
\text { obligations the CMA must follow before it sanctions violators using its } \\
\text { power to refer these to the CMA Board for decision. This should include a } \\
\text { hearing before an impartial/independent third party before the Board makes } \\
\text { it decision. } \\
\text { Consider implementing a formal recusal policy in the Staff Code of Conduct } \\
\text { to require any staff member with a nonfinancial association with any parties } \\
\text { that the staff member may become involved with while undertaking } \\
\text { regulatory work to be excused from participating (whether or not it is clear } \\
\text { at the outset that the association "may potentially impact the CMA or any } \\
\text { of the market participants"). Consider obtaining a positive affirmation from } \\
\text { the CMA staff at regular intervals (such as annually) that they have complied } \\
\text { with the code of conduct (including any investment in mutual funds). }\end{array}$ \\
\hline $\begin{array}{l}\text { Principles Relating to Self-Regulation } \\
\text { (Principles 6-7) }\end{array}$ & $\begin{array}{l}\text { The CMA should commence its consideration of the complex regulatory } \\
\text { issues and changes to its existing method of operating it would need to } \\
\text { implement if the government were to decide that it will proceed with a } \\
\text { self-listing of Tadawul. }\end{array}$ \\
\hline $\begin{array}{l}\text { Principles Relating to Enforcement } \\
\text { (Principles 8-10) }\end{array}$ & $\begin{array}{l}\text { Exercise enforcement powers in a transparent way in all appropriate cases } \\
\text { and publish all outcomes in order to demonstrate regulatory action and } \\
\text { obtain deterrent effect by the CMA's imposition of credible and } \\
\text { proportionate sanctions. Consider if size of maximum fines is sufficient. }\end{array}$ \\
\hline $\begin{array}{l}\text { Principles Relating to Cooperation } \\
\text { (Principles 11-13) }\end{array}$ & $\begin{array}{l}\text { Draft the nature of conditions on release of confidential regulatory } \\
\text { information to foreign regulators so that the CMA can protect its rights in } \\
\text { respect of such information when the circumstances arise in the future, } \\
\text { keeping in mind requirements and limitations in IOSCO MMOU. } \\
\text { Execute and publicly release the proposed MOU with SAMA to set out the } \\
\text { relationship between the two agencies. }\end{array}$ \\
\hline $\begin{array}{l}\text { Principles Relating to Issuers } \\
\text { (Principles 14-16) }\end{array}$ & $\begin{array}{l}\text { Clarify the CMA's role relating to corporate governance and the duties of } \\
\text { directors of listed companies by seeking the appropriate amendments to } \\
\text { MOCI and the CMA legislation, to give the CMA the unambiguous } \\
\text { responsibility for enforcing these provisions in respect of listed companies. } \\
\text { Once enacted, issue guidance to all listed companies together with } \\
\text { appropriate explanation of the CMA's interpretation of these requirements } \\
\text { clearly setting out the mandatory provisions and those that are comply or } \\
\text { explain. } \\
\text { Review the CMA's mandatory obligation to comply with SOCPA } \\
\text { accounting standards for nonbank, noninsurance listed companies. Develop a } \\
\text { timetable in which all companies will adopt and comply with IFRS. }\end{array}$ \\
\hline Principles Relating to (CIS)(Principles 17-20) & $\begin{array}{l}\text { Consider mandating specific disclosure of fund assets (for example the top } \\
10 \text { assets) to assist unit holders monitor their investment in the fund. } \\
\text { Adopt requirements for a custodian to be someone other than the fund } \\
\text { manager, preferably an independent third party; add specific audit } \\
\text { requirements for independent operation and additional verification of assets } \\
\text { if custodian permitted to be an affiliate of the manager. } \\
\text { Complete the CMA review of pricing and amend the regulations that apply }\end{array}$ \\
\hline
\end{tabular}




\begin{tabular}{|c|c|}
\hline Principle & Recommended Action \\
\hline & $\begin{array}{l}\text { to investment funds and its requirements relating to pricing errors and obtain } \\
\text { specific authority to require notification and permit it to take appropriate } \\
\text { action with respect to the suspension or deferral of redemption rights. } \\
\text { Provide additional written guidance on the valuation of fund assets, } \\
\text { particularly those where market prices are not available. }\end{array}$ \\
\hline $\begin{array}{l}\text { Principles Relating to Market Intermediaries } \\
\text { (Principles 21-24) }\end{array}$ & $\begin{array}{l}\text { Introduce an express provision for AP's to maintain copies of its calculations } \\
\text { of capital adequacy on a daily basis. } \\
\text { Revise the content of the Guidance Note on capital adequacy as proposed to } \\
\text { make the content less technical and more flexible for large exposures and } \\
\text { asset valuation and publish it as a separate implementing regulation. } \\
\text { Determine whether professional indemnity and/or fidelity insurance should } \\
\text { be mandatory (having regard to the risks to which an AP is exposed). } \\
\text { Review the provisions regularly so as to take into account risk-based factors } \\
\text { in the market. } \\
\text { Prepare a plan to deal with an insolvency of a market intermediary. } \\
\text { Obtain agreement internally and with other stakeholders such as SAMA and } \\
\text { MOCI on a procedure to apply in the unlikely event of an unexpected AP } \\
\text { insolvency and document same. }\end{array}$ \\
\hline $\begin{array}{l}\text { Principles Relating to Secondary Markets } \\
\text { (Principles 25-29) }\end{array}$ & $\begin{array}{l}\text { Develop strategy for the future of Tadawul, including whether it should } \\
\text { conduct any regulatory functions and determine regulatory changes to CML } \\
\text { required if it does not continue to be a wholly-owned entity of government } \\
\text { under the full control of the CMA. Consider introducing a requirement to } \\
\text { require licensing of any trading systems, including securities exchanges, } \\
\text { setting out objective criteria for approval and providing a mechanism for } \\
\text { regulatory authorization, should such a development eventuate in the future. } \\
\text { Demonstrate publicly the CMA's track record of enforcement of its powers } \\
\text { relating to market misconduct (appropriately specifying and articulating } \\
\text { manipulative and other unfair market practices) and remedy the lack of } \\
\text { transparency of the outcomes it has achieved by specifying for each case, the } \\
\text { details of the conduct involved. }\end{array}$ \\
\hline
\end{tabular}




\section{Authorities' Response to the AsSessment}

30. The authorities provided comments on the detailed assessment report, most of which have already been incorporated, including the correction of some factual errors. With regard to four substantive findings in the assessment, the authorities highlighted:

- $\quad$ The assumed conflict of interest that is arising from the CMA's power to appoint CRSD members is eliminated by the fact that the members of the Appeal Panel, whose decisions are final and supersede those of the CRSD, are appointed by the Council of Ministers.

- $\quad$ Although not all enforcement outcomes are publicized, the significant ones are, since all sanctions imposed by CRSD resolutions and some of the CMA's Board resolutions are announced to the public.

- $\quad$ There are no inconsistencies between the Companies Law and the CMA's corporate governance requirements. Listed Companies have to comply with the Companies Law and the mandatory articles of the Corporate Governance Regulations (CGRs). None of the mandatory Articles in the CGRs are imposed by the Companies Law, nor are they inconsistent with any provision of the Companies Law.

- $\quad$ The CMA's Board members may only be removed by a Royal Order, which is subject to applicable procedural rules. Thus, this aspect of the assessment is unclear and would seem to be redundant.

These comments were considered by the assessor, but not endorsed. 
FinANCIAL SeCtor Assessment PROGRAM UPDATE

\section{SAUDI ARABIA}

BASEl CORE PRINCIPLES FOR EFFECTIVE BANKING

SUPERVISION

REPORT ON STANDARDS

AND CODES (ROSC)

JUNE 2011

INTERNATIONAL MONETARY FUND

MONETARY AND CAPITAL MARKETS DEPARTMENT
THE WORLD BANK Financial and PRIVATe SeCtor Vice PRESIDENCY Middle EAST AND North Africa Vice PRESIDENCY 
Glossary 3

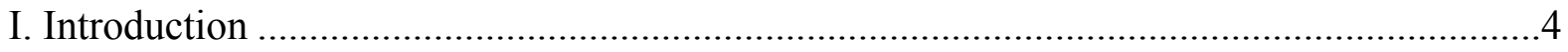

II. Information and Methodology Used for Assessment................................................

III. Institutional and Macroeconomic Setting and Market Structure-Overview ...................4

IV. Preconditions for Effective Banking Supervision .................................................

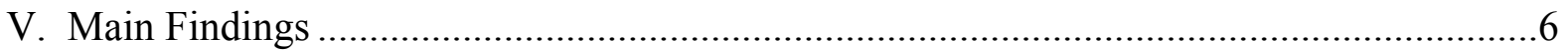

VI. Authorities' Response to the Assessment................................................................ 13

Tables

1. Summary of Compliance with the Basel Core Principles-Report on the Observance

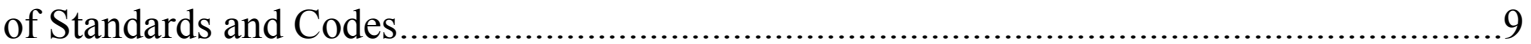

2. Recommended Action Plan to Improve Compliance with the Basel Core Principles ........11 


\section{GLOSSARY}

$\begin{array}{ll}\text { BCL } & \text { Banking Control Law } \\ \text { CMA } & \text { Capital Market Authority } \\ \text { CP } & \text { Core Principle } \\ \text { ELA } & \text { Emergency Liquidity Assistance } \\ \text { ERMS } & \text { Electronic Return Management System } \\ \text { FSAP } & \text { Financial Sector Assessment Program } \\ \text { IFRS } & \text { International Financial Reporting Standards } \\ \text { ISA } & \text { International Standards of Auditing } \\ \text { MOF } & \text { Ministry of Finance } \\ \text { MOU } & \text { Memorandum of Understanding } \\ \text { NPL } & \text { Nonperforming loan } \\ \text { RBA } & \text { Risk-based approach } \\ \text { SR } & \text { Saudi Riyal } \\ \text { SAMA } & \text { Saudi Arabia Monetary Agency }\end{array}$




\section{INTRODUCTION}

1. This assessment of Saudi Arabian Monetary Agency's (SAMA) compliance with the Basel Committee's Core Principles for Effective Banking Supervision was conducted by a mission to Saudi Arabia during April 9 to 20, 2011. The assessment was carried out as part of a Financial Sector Assessment Program (FSAP) Update undertaken by the IMF and the World Bank at the request of the Saudi authorities. The authorities requested that the assessment of compliance be conducted using only the essential criteria in the methodology. The assessment was conducted by Peter Hayward (IMF consultant) and Cédric Mousset (World Bank).

\section{INFORMATION AND METHODOLOGY USED FOR ASSESSMENT}

2. This assessment was based on a review of laws, regulations, policies and practices in place at the time. It was based on the 1966 Banking Control Law (BCL) and its implementing ministerial decision, the 1957 SAMA Charter, circulars issued by SAMA, as well the Code of Corporate Governance issued by the Capital Markets Authority (CMA). Other sources included a self-assessment, detailed interviews with staff from SAMA and internal reports, as well as external meetings with banks, external audit firms and a lawyer. All interlocutors responded freely to the mission. Material included reports and assessments where they were prepared in English, such as full-scope examinations, prepared by external audit firms, but not other reports prepared in Arabic and not available to non-Arabic speakers. The assessment was conducted using the 2006 methodology published by the Basel Committee for Banking Supervision. ${ }^{1}$

\section{Institutional And Macroeconomic Setting And Market Structure- OVERVIEW}

3. Saudi Arabia confronted the global financial crisis from a position of strength. In the years before the crisis, the authorities strengthened the balance sheet of the government and enhanced the financial sector's resilience. A strong policy response moderated the impact of the crisis.

4. Commercial banks are the largest sector of the financial system. As of December 2010, there were 23 licensed banks, but only 20 are "active." Of these, 12 are Saudi incorporated banks, whose assets account for 98 percent of the banking system assets, or more than half of total financial system assets and 85 percent of GDP. As a percentage of GDP, bank assets and credit are comparable to those in other countries with similar characteristics. However, as in the case of other Gulf Cooperation Council countries, loan portfolios are concentrated, reflecting limited lending to sectors such as small- and medium-

\footnotetext{
${ }^{1}$ See http://www.bis.org/publ/bcbs130.htm
} 
scale enterprises (SMEs) and housing. Credit concentration risk has been mitigated by high capital requirements. Sharia-compliant products are offered by commercial banks based on a single license for commercial banks. Products offered are mainly "plain vanilla" (for example installment sales) and primarily involve credit risk, and do not require sophisticated supervisory approaches.

5. The banking sector is fairly concentrated around a few banks. The seven largest banks have a combined share of assets of 85 percent. The three largest have a combined share of about 45 percent, and the next four each have market shares exceeding 5 percent. The dominant shareholders of the three largest banks are government entities, the fourth largest is linked to a family business group, and the next three have ties to major international banks. All banks with government participations appear to be run on a commercial basis. In addition, all banks but the largest (state-owned) are listed. This reflects a policy designed to ensure arm's-length relationships between banks and the large family-owned groups, and to promote Saudi citizen investments in banks. The market shares of the long established institutions have not been significantly affected by the entry of new banks in recent years. SAMA licensed two domestic banks in the mid-2000s, as well as several branches of foreign banks. The two new banks only account for 3 percent of banking assets, and foreign branches remain niche players with a 2 percent market share.

6. The banking sector overall is well capitalized and profitable. The solvency ratio for the sector as a whole was above 17 percent in December 2010, having declined from about 21 percent in December 2007. The main causes of the sharp decline in capital adequacy ratios between 2007 and 2008 (16 percent) are a new operational risk charge due to the implementation of Basel 2 and rapid asset growth coupled with slower growth of own funds. The Tier 1 capital ratio is about 15 percent (end-2010). After a credit squeeze in 2009, credit growth picked up in 2010, thus far without any deterioration in asset quality. Credit declined by 1 percent over the 12 months to December 2009, but increased by 5 percent in the following 12 months. The nonperforming loan (NPL) ratio has remained broadly at 3 percent, with provisions covering 116 percent of NPLs in December 2010. ${ }^{2}$ Loans are the largest bank asset class (54 percent of banks' aggregate balance sheet at end-2010). Liquidity appears to be adequate. Profitability weakened during the crisis, but appears to be recovering in 2010. Return on assets was nearly 2 percent and return on equity 13.6 percent in December 2010, compared with 2.8 percent and 22.3 percent in December 2007.

\section{Preconditions For EfFective Banking SuPERVISION}

\section{The financial system is subject to risks reflecting the openness of the economy} and dependence on the hydrocarbon sector, as well as the size of the market. A relatively simple banking system centered on core banking activities makes supervision

\footnotetext{
${ }^{2}$ Raw data received from SAMA shows a provisioning ratio of 90 percent.
} 
relatively straightforward. Any growth in the use of more sophisticated products and forms of intermediation will require a more elaborate and formal supervisory approach.

8. The financial infrastructure is being strengthened. The old and ineffective collateral regime is progressively being improved, especially for real estate. Enforcement of real estate collateral remains difficult and lengthy. The situation is worse in the case of movables. A package of five draft laws recently approved by the Shura Council and submitted to the Council of Ministers includes an Enforcement Law that is expected to improve the effectiveness of enforcement procedures for all types of collateral. ${ }^{3}$ Saudi Arabia's credit reporting system has improved in recent years thanks to the modern private Saudi Credit Bureau.

9. Saudi Arabia implements International Financial Reporting Standards (IFRS) for banks and insurance companies and is served by the major accounting firms. Listed companies apply local generally accepted accounting principles and auditing standards set by Saudi Organization for Certified Public Accountants, which are not as comprehensive and detailed as International Financial Reporting Standards (IFRS) and International Standards of Auditing (ISA).

10. Saudi Arabia does not have a formal deposit insurance scheme. There has been no need to provide emergency liquidity assistance (ELA) to any bank in recent years. The conditions in which SAMA would provide ELA would be determined on a case-by-case basis, as would the terms on which such ELA would be provided.

\section{MAIn FindingS}

\section{There have been significant improvements in banking regulation and} supervision since the 2004 FSAP. SAMA made efforts to introduce Basel II, and used the Pillar 2 requirements to foster improvements in banks' risk management and capital planning. In supervision, risk-based approaches have been introduced and large resources allocated to supervision, with overall staffing now around 200 people (a doubling over the past five years). SAMA has also initiated the introduction of Basel III requirements.

\section{The assessment can be summarized as follows:}

- Objectives, independence, powers, transparency, and cooperation (CP1). The legal framework is old; the BCL has hardly been changed since enactment in 1966. It should be updated, especially as it provides for much less formal independence and authority for SAMA than is exercised in practice. SAMA, however, considers that the BCL has served it well and believes that there would be more risk than benefits in amending it. The planned

\footnotetext{
${ }^{3}$ Saudi Arabia is a monarchy and legislation is by resolution, ratified by the King (royal decree).
} 
codification of the numerous circulars and other communications with banks will help. The framework has not been an impediment to effective supervision, as SAMA has been able to take adequate actions without using formal legal powers (a situation explained by its standing and credibility as well as the limited number of banks). The BCL could be updated to remove the need for government approval to license banks and impose sanctions, issue regulations, conduct inspections, and put SAMA's present autonomy in practice on a statutory basis to ensure it remains effective. Provisions could also be added to provide legal protection to supervisors, require SAMA's approval in case of transfer of significant ownership, create a bank resolution framework, and provide a clear mandate to exercise consolidated supervision and share information for supervisory purposes.

- Licensing and structure (CPs 2-5). The prudent licensing approach implemented by SAMA could benefit from a legal definition of SAMA's objectives and improved disclosure of its expectations for new banks. There are no published objectives for supervision, an omission that should be addressed in the law. Only two banks have been licensed in the last decade (one state-owned, one resulting from the merger of money changers), and new foreign bank branches remain marginal players. To make clear that the market is contestable, SAMA should publish its detailed criteria for licensing new banks, fully align them with objectives focused on safety and soundness, and withdraw the requirement that new licensees should "add value." Similarly, legal requirements for SAMA to approve any new bank outlet (i.e., branch or automated teller machine) could usefully be removed so that such risks can be covered within the risk-based process (i.e., ex post rather than ex ante). Although SAMA has effectively controlled changes in ownership, the legal basis for doing so is not robust and this should be remedied.

- Prudential regulation and requirements (CPs 6-18). SAMA has made substantial efforts to introduce Basel II. It should complement recent strides in banks' risk management by an improved regime for large exposures and connected parties. Much of the risk management guidance appears in the various Basel II documents (which do not apply to foreign branches). A framework circular should be issued bringing all aspects of risk management into one document, and updating requirements on market risk and internal controls to reflect developments in the last decade. Widespread bank losses caused by the 2009 failure of Al-Gossaibi \& Bros. Co. and the Saad Group, two large well-established family groups, suggest that there may have been weaknesses in credit risk management. ${ }^{4}$ SAMA has responded to this default, including by ensuring that losses were fully provisioned and by spearheading a dialogue with the banking industry to identify relevant lessons. In a system characterized by high single-name concentration, attention to individual large exposures should be intensified, in particular during on-site inspections. The possibility for SAMA to allow large exposures of as much as 50 percent of capital, which was recently used, should

${ }^{4}$ Both Saudi and foreign banks, including large international banks, were significantly exposed to these groups. 
also be removed (with the maximum exposure capped at, for example, 25 percent of capital). The definition of related parties needs to be strengthened to ensure that close family relationships are taken into account.

- Methods of ongoing banking supervision (CPs 19-21). SAMA has made progress in implementing a risk-based approach and should complete this transition. The supervisory regime still includes broad requirements for banks to obtain SAMA's ex ante approval (for example, before opening branches, before lending to a nonresident, before releasing financial statements, before launching new products). In recent years, the introduction of the risk-based approach triggered a welcome intensification of contacts with banks as part of off-site supervision. SAMA has maintained an intrusive on-site process, which relies primarily on full-scope examinations and, to a growing extent, on focused ones. The schedule for full-scope examinations should be better defined to avoid crowding effects (that is, most banks were covered in 2007 and 2008, but only one in 2009 and 2010); examinations should focus more on actual risks and banks' ability to manage them; and increased attention should be paid to branches of foreign banks. More systematic on-site verification of prudential reporting may also be needed.

- Accounting and disclosure (CP 22). SAMA has for a long time encouraged banks to build prudent capital and provisioning buffers, based on reliable financial statements. Such buffers have proved valuable in recent years in allowing the impact of the global crisis and the default of two large groups to be absorbed without threatening any bank. Capital buffers are now defined as part of the ICAAP process, while provisioning buffers result from pragmatic decisions from SAMA's senior management. The latter would benefit from being more formalized. SAMA has successfully introduced international accounting and auditing standards (IFRS and ISA) for banks and their auditors. It also introduced Pillar 3 disclosure requirements in 2008 as part of the implementation of Basel II.

- Corrective and remedial powers of supervisors (CP 23). SAMA's proactive style of supervision has meant that formal enforcement action has rarely been needed, but removal of the statutory need for government approval of the exercise of its powers would safeguard its independence. SAMA should take the opportunity, already taken by many other countries, to establish a specific bankruptcy regime for banks, and ideally a specific resolution regime.

- Consolidated and cross-border banking supervision (CPs 24-25). While SAMA's exercise of its consolidated supervision authority has been effective, some banks are beginning to expand across border quite aggressively and this could prove a challenge to group managements and boards, and thus to supervisors. SAMA has good contacts with the CMA and with foreign supervisors. The draft memorandum of understanding (MOU) with the CMA should be finalized and exchange of inspection reports and common on-site work initiated. SAMA should also give thought to the advantages of having written agreements with foreign supervisors so that cooperation can be effective in any unforeseen emergency. 


\section{Table 1. Saudi Arabia: Summary of Compliance with the Basel Core Principles-Report on the Observance of Standards and Codes}

\begin{tabular}{|c|c|}
\hline Core Principle & Comments \\
\hline \multicolumn{2}{|l|}{$\begin{array}{l}\text { 1. Objectives, independence, powers, } \\
\text { transparency, and cooperation }\end{array}$} \\
\hline 1.1 Responsibilities and objectives & SAMA's objectives are not defined. \\
\hline $\begin{array}{l}1.2 \text { Independence, accountability and } \\
\text { transparency }\end{array}$ & $\begin{array}{l}\text { The approval/action of the Ministry of Finance (MOF) or } \\
\text { Council of Ministers is needed for key regulatory and } \\
\text { supervisory actions. }\end{array}$ \\
\hline 1.3 Legal framework & $\begin{array}{l}\text { The BCL has not been updated, nor are all circulars easily and } \\
\text { publicly available. }\end{array}$ \\
\hline 1.4 Legal powers & $\begin{array}{l}\text { The approval/action of the MOF or Council of Ministers is } \\
\text { needed for key regulatory and supervisory actions. }\end{array}$ \\
\hline 1.5 Legal protection & $\begin{array}{l}\text { Supervisors (agency and staff) do not benefit from clear legal } \\
\text { protection. }\end{array}$ \\
\hline 1.6 Cooperation & A draft MOU between the CMA and SAMA is being finalized. \\
\hline 2. Permissible activities & Activities effectively controlled and term 'bank' protected. \\
\hline 3. Licensing criteria & $\begin{array}{l}\text { Core criteria used by SAMA to review licensing applications are } \\
\text { not made public. } \\
\text { Core licensing criteria include a need for a new bank to "add } \\
\text { value," which is unrelated to safety and soundness. }\end{array}$ \\
\hline 4. Transfer of significant ownership & $\begin{array}{l}\text { There are no legal provisions on the transfer of significant } \\
\text { ownership. }\end{array}$ \\
\hline 5. Major acquisitions & $\begin{array}{l}\text { Limits on investments are applied and acquisitions subjected to } \\
\text { supervisory approval. }\end{array}$ \\
\hline 6. Capital adequacy & Minimum capital ratios well exceed Basel requirements. \\
\hline 7. Risk management process & $\begin{array}{l}\text { Key risk management requirements can be only indirectly } \\
\text { imposed on banks and branches of foreign banks. }\end{array}$ \\
\hline 8. Credit risk & $\begin{array}{l}\text { Recent large corporate failures may require some strengthening } \\
\text { of credit risk regulation. }\end{array}$ \\
\hline 9. Problem assets, provisions, and reserves & $\begin{array}{l}\text { Portfolio approach may need to be supplemented by more on-site } \\
\text { assessment of individual risks. }\end{array}$ \\
\hline 10. Large exposure limits & $\begin{array}{l}\text { The large exposure limit can be raised to } 50 \text { percent (a possibility } \\
\text { sometimes used by SAMA). } \\
\text { Supervision is not implemented systematically during full scope } \\
\text { on-site inspections (definition of connected parties). }\end{array}$ \\
\hline 11. Exposure to related parties & $\begin{array}{l}\text { The definition of related parties is not comprehensive (for } \\
\text { example, senior management, close family members). } \\
\text { Supervision is not implemented systematically during full scope } \\
\text { on-site inspections (definition of related parties). }\end{array}$ \\
\hline 12. Country and transfer risks & Risks are extensively reported and are low. \\
\hline
\end{tabular}




\begin{tabular}{|c|c|}
\hline 13. Market risks & $\begin{array}{l}\text { Existing guidance does not cover all derivative activities, nor } \\
\text { incorporate recent best practices. Some core requirements are not } \\
\text { binding. }\end{array}$ \\
\hline 14. Liquidity risk & Basel III approach is to be implemented. \\
\hline 15. Operational risk & $\begin{array}{l}\text { A capital charge is applied and operational risk management } \\
\text { policies are discussed with supervisors. }\end{array}$ \\
\hline 16. Interest rate risk in the banking book & $\begin{array}{l}\text { Risk levels are low but are considered in the internal capital } \\
\text { adequacy assessment process. }\end{array}$ \\
\hline 17. Internal control and audit & Framework is comprehensive but could be updated. \\
\hline 18. Abuse of financial services & $\begin{array}{l}\text { On-site inspection plan generates concentration on a few years } \\
\text { (see CP 20). }\end{array}$ \\
\hline 19. Supervisory approach & $\begin{array}{l}\text { Supervisory risk ratings are not differentiated. } \\
\text { Risk profiles are sometimes not updated at least annually. }\end{array}$ \\
\hline 20. Supervisory techniques & $\begin{array}{l}\text { The on-site full scope examination plan generates a } \\
\text { concentration on a few years (and a lack of such examinations } \\
\text { during others). } \\
\text { Limited scope examinations remain primarily compliance } \\
\text { oriented. } \\
\text { Full-scope examinations do not always pay attention to assessing } \\
\text { adequacy of provisioning of individual exposures. } \\
\text { Meetings with the full Board are not organized. }\end{array}$ \\
\hline 21. Supervisory reporting & $\begin{array}{l}\text { Full-scope on-site inspections do not always assess the reliability } \\
\text { of electronic return management system (ERMS) returns. }\end{array}$ \\
\hline 22. Accounting and disclosure & $\begin{array}{l}\text { The process followed to set provisioning buffers which banks } \\
\text { should hold is not formalized. }\end{array}$ \\
\hline $\begin{array}{l}\text { 23. Corrective and remedial powers of } \\
\text { supervisors }\end{array}$ & $\begin{array}{l}\text { The exercise of formal supervisory action requires an approval } \\
\text { outside SAMA (for example, MOF). } \\
\text { There is no specific bankruptcy regime for banks. }\end{array}$ \\
\hline 24. Consolidated supervision & $\begin{array}{l}\text { SAMA does not have a clearly defined power to conduct } \\
\text { consolidated supervision. } \\
\text { Banks' group internal control/risk management frameworks are } \\
\text { not always assessed during full-scope on-site inspections. }\end{array}$ \\
\hline 25. Home-host relationships & $\begin{array}{l}\text { The BCL does not contemplate a lifting of its confidentiality } \\
\text { requirements when necessary. } \\
\text { There are no MOU with foreign supervisors. }\end{array}$ \\
\hline
\end{tabular}




\section{Table 2. Saudi Arabia: Recommended Action Plan to Improve Compliance with the Basel Core Principles}

\begin{tabular}{|c|c|}
\hline Reference Principle & Recommended Action \\
\hline 1.1 Responsibilities and objectives & $\begin{array}{l}\text { Introduce better definition of SAMA's objectives (public } \\
\text { statements in the short term, revised law in the medium } \\
\text { term). }\end{array}$ \\
\hline 1.2 Independence, accountability and transparency & $\begin{array}{l}\text { Revise legal requirements to remove the need that the MOF } \\
\text { or Council of Ministers approve or take action to exercise } \\
\text { key regulatory and supervisory powers. }\end{array}$ \\
\hline 1.3 Legal framework & $\begin{array}{l}\text { Update the BCL (see details under other CPs), codify all } \\
\text { circulars and make them publicly available. }\end{array}$ \\
\hline 1.4 Legal powers & $\begin{array}{l}\text { Revise legal requirements to remove the need that the MOF } \\
\text { or Council of Ministers approve or take action to exercise } \\
\text { key regulatory and supervisory powers. }\end{array}$ \\
\hline 1.5 Legal protection & Introduce clear legal protection for supervisors. \\
\hline 1.6 Cooperation & Finalize the draft MOU between the CMA and SAMA. \\
\hline \multicolumn{2}{|l|}{ 2. Permissible activities } \\
\hline 3. Licensing criteria & $\begin{array}{l}\text { Make SAMA core criteria for reviewing license applications } \\
\text { public and remove the need for a new bank to "add value." }\end{array}$ \\
\hline 4. Transfer of significant ownership & $\begin{array}{l}\text { Introduce legal provisions on the transfer of significant } \\
\text { ownership. }\end{array}$ \\
\hline \multicolumn{2}{|l|}{ 5. Major acquisitions } \\
\hline \multicolumn{2}{|l|}{ 6. Capital adequacy } \\
\hline 7. Risk management process & Issue circular covering key risk management requirements. \\
\hline 8. Credit risk & Strengthen further credit risk regulation. \\
\hline \multicolumn{2}{|l|}{ 9. Problem assets, provisions, and reserves } \\
\hline 10. Large exposure limits & $\begin{array}{l}\text { Update the large exposure regulation (for example, remove } \\
\text { possibility to raise limit to } 50 \text { percent, derivatives risk } \\
\text { weighting). } \\
\text { Implement supervision more systematically (for example, } \\
\text { definition of connected parties). }\end{array}$ \\
\hline 11. Exposure to related parties & $\begin{array}{l}\text { Broaden the definition of related parties to include close } \\
\text { family members and key staff. } \\
\text { Implement supervision more systematically (for example, } \\
\text { definition of related parties). }\end{array}$ \\
\hline \multicolumn{2}{|l|}{ 12. Country and transfer risks } \\
\hline 13. Market risks & $\begin{array}{l}\text { Update requirements to cover all derivative activities, } \\
\text { incorporate recent best practices, and make core } \\
\text { requirements binding. }\end{array}$ \\
\hline \multicolumn{2}{|l|}{ 14. Liquidity risk } \\
\hline 15. Operational risk & \\
\hline
\end{tabular}




\begin{tabular}{|c|c|}
\hline Reference Principle & Recommended Action \\
\hline 16. Interest rate risk in the banking book & \\
\hline 17. Internal control and audit & Internal control requirement should be updated. \\
\hline 18. Abuse of financial services & $\begin{array}{l}\text { Better define the examination program to avoid crowding } \\
\text { effects. }\end{array}$ \\
\hline 19. Supervisory approach & $\begin{array}{l}\text { Differentiate banks' risk ratings more and update risk } \\
\text { profiles at least annually. }\end{array}$ \\
\hline 20. Supervisory techniques & $\begin{array}{l}\text { Better define the full-scope examination program to avoid } \\
\text { crowding effects. } \\
\text { Focus limited scope examinations more on actual risks and } \\
\text { banks' ability to manage them. } \\
\text { Pay more attention on-site to assessing large exposures and } \\
\text { the adequacy of provisioning of individual exposures. } \\
\text { Consider introducing meetings with the full Board as part of } \\
\text { the off-site process. }\end{array}$ \\
\hline 21. Supervisory reporting & $\begin{array}{l}\text { Ensure that the reliability of ERMS returns is systematically } \\
\text { assessed on-site. }\end{array}$ \\
\hline 22. Accounting and disclosure & $\begin{array}{l}\text { Formalize the process followed to set provisioning buffers } \\
\text { which banks should hold. }\end{array}$ \\
\hline 23. Corrective and remedial powers of supervisors & $\begin{array}{l}\text { Remove the need for any approval/action outside SAMA to } \\
\text { exercise formal supervisory action (for example, MOF). } \\
\text { Establish a specific bankruptcy regime for banks, and } \\
\text { consider introducing a special resolution regime. }\end{array}$ \\
\hline 24. Consolidated supervision & $\begin{array}{l}\text { Revise legal requirements to give SAMA a stronger legal } \\
\text { basis to conduct consolidated supervision. } \\
\text { Review more systematically banks' group internal } \\
\text { control/risk management frameworks during on-site } \\
\text { inspections. }\end{array}$ \\
\hline 25. Home-host relationships & $\begin{array}{l}\text { Update the BCL to lift confidentiality requirements when } \\
\text { necessary (for example, to share information for supervisory } \\
\text { purposes). } \\
\text { Establish MOUs with relevant foreign supervisors. }\end{array}$ \\
\hline
\end{tabular}




\section{Authorities' Response to the ASSESSMEnt}

13. Saudi Arabia supports the FSAP, which intends to promote stability of the financial systems and best supervisory practices. The authorities appreciate the efforts and commitment of the FSAP team for timely completion of this assessment. The authorities are broadly in agreement with the overall findings, but have reservations on certain aspects of the assessment. The assessment has rightly acknowledged that Saudi Arabia confronted the global financial crisis from a position of strength and that there have been significant improvements in banking regulation and supervision since the 2004 FSAP. However, the assessment has somehow not fully reflected several actions taken by Saudi Arabia to strengthen the supervisory framework. The authorities were expecting the assessment to focus more on qualitative aspects of Saudi Arabia's regulatory and supervisory framework, keeping in view the local and regional context and taking into account the ground realities.

\section{The authorities believe that the grading of certain Core Principles (CP) is not} reflecting the substantial progress made in strengthening the supervisory oversight. For example, all the requirements of CP 1(3) and 1(4) are fully met, and the assessment does not identify any material deficiencies. Regarding CP 1(5), legal protection of SAMA or its staff has never been an issue given that there is adequate protection available in the general laws and no supervisory action has ever been challenged in a court of law. Similarly, the grading of CP 4, 10 and 11 is not justified and, based on the comments conveyed earlier, should have been upgraded. In fact, CP 10 (large exposure limits) was downgraded from an initially higher rating without any explanation. The authorities also believe that the existing BCL of Saudi Arabia is serving the purpose well and provides the necessary legal framework for implementing international standards and for taking all the required supervisory actions. For example, in exercise of powers under this law, SAMA has already implemented Basel-II / Basel-III and all other relevant international standards. As was explained elaborately to the FSAP team, legal systems vary in their approaches. Hence, appreciation for such diversity in legal cultures was in order. However, the authorities will review the other FSAP recommendations and take appropriate actions in line with the existing legal and regulatory framework. 
FINANCIAL SECTOR ASSESSMENT PROGRAM

\section{SAUDI ARABIA}

ASSESSMENTS OF OBSERVANCE OF CPSS CORE PRINCIPLES FOR SYSTEMICALLY IMPORTANT PAYMENT SYSTEMS

\section{REPORT ON STANDARDS AND CODES (ROSC)}

JUNE 2011

INTERNATIONAL MONETARY FUND MONETARY AND CAPITAL MARKETS DEPARTMENT
THE WORLD BANK

FinANCIAL SECtor Vice PRESIDENCY Middle East And North Africa Region

VICE PRESIDENCY 


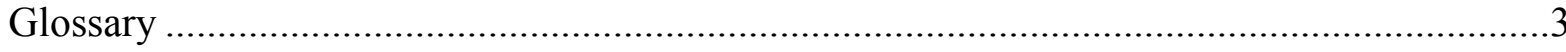

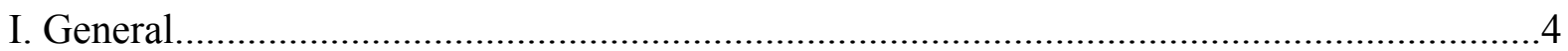

II. Institutional and Market Structure............................................................................4

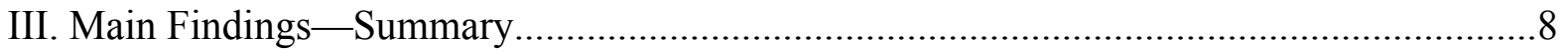

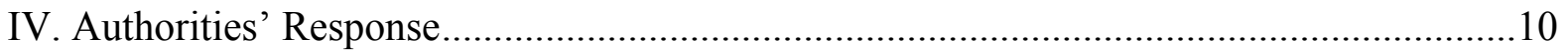

\section{Tables}

1. Recommended Actions to Improve Observance of CPSS Core Principles and Central Bank Responsibilities in Applying CPs-SARIE ....................................................8 


\section{GLOSSARY}

ATM

BCL

BTD

CMA

$\mathrm{CP}$

CPSIPS

CPSS

DVP

ETC

FSAP

IOSCO

$\mathrm{MOU}$

NPS

ORR

RTGS

SAMA

SARIE

SDC

SSS
Automated Teller Machine

Banking Control Law

Banking Technology Department

Capital Markets Authority

Core Principle

Core Principles for Systemically Important Payment Systems

Committee on Payment and Settlement Systems

Delivery-versus-Payment

Exchange Traded Fund

Financial Sector Assessment Program

International Organization of Securities Commissions

Memorandum of Understanding

National Payments System

Operating Rules and Regulations

Real Time Gross Settlement

Saudi Arabian Monetary Agency

Saudi Arabian Riyal Inter-bank Express

Securities Depository Center

Securities Settlement System 


\section{General}

1. This assessment of the systemically important payment systems in Saudi Arabia is based on the Core Principles for Systematically Important Payment Systems (CPSIPS). The assessment was conducted in the context of the mission of the Financial Sector Assessment Program (FSAP) Update to Saudi Arabia in April 2011. The assessor of the CPSIPS was Massimo Cirasino. ${ }^{1}$

2. The information used included all relevant laws, rules and procedures governing payment and securities settlement systems, and the abundant material available on the issue inside and outside the central bank and securities commission. In addition, extensive discussions were held with different departments of regulators and overseers; Saudi Arabian Monetary Agency (SAMA) ${ }^{2}$ and the Capital Markets Authority (CMA); several stakeholders in the Saudi Arabia payments system, including four commercial banks (SABB, Bank Saudi Fransi, Saudi Investment Bank, SAMBA); the stock exchange, Tadawul; the Securities Depository Center (SDC); and a broker/dealer (Jadwa Investment). Self assessments by SAMA of the country's main payment systems (Saudi Arabian Riyal InterBank Express (SARIE), SPAN, SADAD, and the check clearing process) were provided to the assessor prior to the mission. The self-assessments were prepared by SAMA's Banking Technology Department (BTD), in close consultation with system participants. The self assessment of the securities settlement system (SSS) with the CPSS International Organization of Securities Commissions (IOSCO) Recommendations for SSS, performed by the CMA, was also provided. The SAMA answers to the questionnaire of the World Bank Global Payment System Survey were also used.

3. In addition to the 2001 CPSS-CPSIPS Report, the methodology used follows the Guidance Note for Assessing Observance of CPSIPS prepared by the IMF and the World Bank in collaboration with the CPSS in August 2001.

\section{InStitutional AND MARKet STRUCTURE}

4. The National Payments System (NPS) in Saudi Arabia is comprehensive and designed to serve the needs of a broad set of users. The infrastructure operated by SAMA is primarily concentrated on payments in Saudi riyals. The payment systems operated by SAMA are as follows: (i) the SARIE real time gross settlement (RTGS) system processes a wide range of high and low value payments and provides settlement facilities for a number of clearing systems, as well as for transactions executed at the Tadawul stock exchange; (ii) check clearing houses operated at SAMA branches throughout Saudi Arabia;

\footnotetext{
${ }^{1}$ Head of the Financial Infrastructure Unit and the Payment Systems Development Group of the Financial and Private Sector Development Vice Presidency at the World Bank.

${ }^{2}$ The BTD at SAMA is also the operator of a number of payment systems.
} 
(iii) automated teller machine (ATM) and point-of-sale services provided through the SPAN system; (iv) electronic bill presentment and payment processed by the SADAD system; (v) the public key infrastructure, which provides advanced security facilities; and (vi) the SAMA joint network, a highly secured communications network. The NPS in Saudi Arabia is characterized by a high level of standardization.

\section{The legal and regulatory framework for payment and securities settlement} systems includes several pieces of legislation, namely: Central Bank Law; Banking Control Law (BCL); Securities Market Law; Competition Law; Anti-Money Laundering and Combating the Financing of Terrorism (AML/CFT) Law; Electronic Transaction Law; and Central Bank Regulations having the power of Law. In addition, SAMA has issued operating rules and procedures for the various payment systems that it operates: SARIE System Operating Rules and Regulations (ORR); the SPAN Business Books, which define the rules, regulations, and operating procedures for the SPAN system; and the "Rules for Members of the Automated Clearing System;" and the check printing standards for the check clearing houses. SAMA has issued detailed rules on AML and know your customer. Many critical aspects relating to the payment and securities settlement systems are covered in the legal framework; however there is not a payment system law that addresses all the key concepts related to payments and settlement.

6. The SARIE system is the backbone of the NPS. SARIE was launched in 1997, and has been periodically enhanced, with the last software update in May 2008. SARIE processes both large-value and small-value payments; both gross settlement and net settlement; both real-time and deferred settlement; and supports both credit transfers and debit transfers. The settlement is effected on the accounts maintained by 20 direct participants with SAMA; all settlements done on SARIE are deemed final and irrevocable. SARIE settles clearing positions from 24 other systems including SPAN, SADAD, and Tadawul. With the exception of Tadawul positions, all the other clearing positions are aggregated and settled on an overall net basis towards the end of the SARIE operating cycle.

7. The usage of SARIE has been steadily increasing. The total value settled has nearly doubled between 2007 and 2010, while the number of transactions processed has grown from 25 to 35 million over the same period. Recently, SAMA has undertaken an Integrated Payments Strategy Review and has proposed some enhancements to SARIE. In particular, the review proposed that the automated clearing house type functionalities be moved onto a separate system. The switch to IBAN requirements for accounts has already been successfully completed and has further increased the efficiency of the system.

\section{Commercial banks are the sole providers of retail payment products in Saudi}

Arabia. The available retail payment instruments are checks, direct debits, credit transfers, and credit and debit cards. Debit cards are the most popular, with around 1.56 million transactions on a daily basis; however, over two-thirds of these are for ATM withdrawals. SAMA and the banks are involved in a massive program to foster inclusion to payment 
services by introducing prepaid cards for the 12 million-strong unbanked and under-banked segments. As mentioned, SAMA is the operator of the major retail payment systems - the clearing house, the card payments switch, and the electronic bill presentment and payment systems.

9. SAMA also manages the clearing and settlement of government securities. These include government development bonds, floating rate notes, and treasury bills (t-bills). SAMA operates a registry with securities accounts for banks investing in government securities. Primary market transactions and secondary market transactions are settled by SAMA against the current accounts of the commercial banks processing the transaction, and the corresponding transfers are recorded in the investors' securities accounts. Currently only banks and government agencies (mainly pension funds) can participate in t-bill auctions, which take place on Mondays and are based on competitive bidding. Ownership is registered at the level of the intermediary and not the beneficial owner. Transactions in the primary market are settled in SARIE on Wednesdays $(\mathrm{T}+2)$. Secondary market transactions among banks are executed by sending instructions between the buyer and the seller via SARIE, and then funds are moved in SARIE itself and securities in the registry.

10. There is a single common central securities depository for corporate securitiesequities and bonds. Around 99.5 percent of negotiable securities in Saudi Arabia are immobilized and dematerialized in the SDC. The SDC handles both equities and bonds, and is used to facilitate transfer of ownership arising from secondary market transactions. Commercial banks, broker-dealers, and other financial institutions are direct participants in the SDC (authorized persons). In all, there are 97 market participants, of which 65 provide services as a dealer. Beneficial owners are identified at the individual level in the SDC, which is a department of Tadawul.

\section{Securities settlement is on a $\mathbf{T}+\mathbf{0}$ settlement cycle for equities and exchange-} traded funds (ETFs) and $\mathbf{T}+\mathbf{2}$ for corporate bonds and Islamic bonds (sukuks) and attempts to conform to a delivery-versus-payment (DVP) model. Equities and ETF transactions are settled real time according to a DVP model 1 arrangement at the level of investors $^{3}$ and corporate bonds and sukuks are settled according to a DVP model 3 arrangement. ${ }^{4}$ Trades are executed only where the seller has the securities in its account at the SDC and the relevant clearing bank will guarantee payment for the securities. The automated trading system automatically checks whether these conditions are met, and will not execute trades that do not meet both conditions. Market participants (broker/dealers) are required to settle the cash leg through a commercial bank of their choice, the clearing bank.

\footnotetext{
3 At the investors' level, the securities and funds legs are both settled on a gross basis throughout the day.

${ }^{4}$ The securities and funds legs are both settled on a net basis at the end of the settlement cycle.
} 
Clearing banks place specific limits for the settlement positions of their market participant clients. The SDC has an interface with SARIE through which the net settlement positions for the clearing banks are reconciled within SARIE at 3:30 p.m. on all trading days, which is then settled in SARIE with finality by 3:40 p.m. Given the retail nature of most transactions in Saudi Arabia's capital markets, individual investors are required to make their securities and funds available prior to executing the transaction. Ownership of securities is transferred upon confirmation of trade and the seller is - in many cases - able to access funds immediately after confirmation and transfer of ownership.

\section{Payment and Securities Settlement Systems Oversight}

12. The power of SAMA to oversee the payment systems is stated in the central bank and banking laws. Reference to SAMA oversight authority is general, in the context of ensuring the adequate and safe functioning of payment systems in the country. However, the powers of the central bank to operate, regulate, and oversee the payment systems are not detailed in the law. The CMA is empowered to oversee and regulate securities settlement aspects.

\section{SAMA is in the process of establishing a full-fledged payment systems oversight}

function. The payment systems oversight function has de facto been performed regularly by SAMA BTD. Currently, BTD is in the process of staffing an oversight unit which is operationally independent from the units that operate the payment systems. SAMA has not set down its oversight policy and objectives in a policy document. In performing its oversight, SAMA classifies payment systems as: (i) SIPS; (ii) retail systems of systemic importance; (iii) retail systems of prominent importance; and (iv) other retail payment systems.

14. SAMA uses various tools in its exercise of oversight. Monitoring, dialogue and moral suasion, and on-site inspections are the most relevant. Issuance of regulations, sanctions and production, and publication of statistics and other analysis are less often used. In 2009, as part of its catalyst role in payment system reforms, SAMA, in close consultation with relevant stakeholders, conducted a comprehensive NPS review in Saudi Arabia.

15. Cooperation in the payment space exists, but is not formalized. SAMA and the CMA currently engage in dialogue with each other. However, there are no formal memoranda of understanding (MOU). Also, SAMA consults and co-operates with payment system stakeholders on specific operational matters, and also holds regular meetings at senior levels to discuss strategic issues. However, no NPS Council/Committee exists. 


\section{MAin Findings-Summary}

16. SARIE is in observance of most of the CPSS CPSIPS. Also, SAMA is in full or broad observance of central bank responsibilities in applying the principles. However, some opportunities for improvement are summarized in Table 1.

\section{Table 1. Saudi Arabia: Recommended Actions to Improve Observance of CPSS Core Principles and Central Bank Responsibilities in Applying the CPs-SARIE}

\begin{tabular}{|c|c|}
\hline Reference principle & Recommended actions \\
\hline $\begin{array}{l}\text { Legal foundation } \\
\text { Core principle } 1\end{array}$ & $\begin{array}{l}\text { Although the regulatory framework as defined by SARIE ORR is sound, } \\
\text { the lack of a specific payment system law excluding explicitly any } \\
\text { conflict with other laws and regulations can give rise to uncertainty on } \\
\text { the legal framework for settlement. SAMA should start a process that } \\
\text { could lead to the enactment of such a law. }\end{array}$ \\
\hline $\begin{array}{l}\text { Understanding and management of risks } \\
\text { Core principles } 2 \text { and } 3\end{array}$ & $\begin{array}{l}\text { Financial risks are properly managed in the SARIE system. As liquidity } \\
\text { is typically abundant, SARIE participants do not use liquidity facilities } \\
\text { extensively. In the medium term, some improvements to liquidity } \\
\text { management could include less discretionary rules and a more } \\
\text { straightforward link between the funds accounts and the securities } \\
\text { accounts of banks in order to activate intraday liquidity facilities in a } \\
\text { more automatic fashion. }\end{array}$ \\
\hline $\begin{array}{l}\text { Settlement } \\
\text { Core principles } 4,5 \text { and } 6\end{array}$ & \\
\hline $\begin{array}{l}\text { Security and operational reliability, and } \\
\text { contingency arrangements } \\
\text { Core principle } 7\end{array}$ & \\
\hline $\begin{array}{l}\text { Efficiency and practicality of the system } \\
\text { Core principle } 8\end{array}$ & $\begin{array}{l}\text { Operating hours and the daily business cycle were amended in } 2006 \text { in } \\
\text { cooperation with system participants. It is likely that operating hours } \\
\text { might need to be extended and the calendar for settlement of other } \\
\text { systems in SARIE reconsidered in light of technological and business } \\
\text { developments. SAMA is engaged in discussions with commercial banks } \\
\text { on this topic. } \\
\text { Banks interviewed during the assessment expressed a high level of } \\
\text { satisfaction with the services provided by SARIE. It was mentioned that } \\
\text { very minor problems have been caused occasionally by data } \\
\text { communication delays. SAMA is working actively to address the issue. } \\
\text { SAMA could also engage in a discussion with participants to verify } \\
\text { whether the settlement of a single netting position for all retail systems } \\
\text { does not expose these systems to operational spillover effects in the event } \\
\text { of problems in one of the clearing processes. }\end{array}$ \\
\hline $\begin{array}{l}\text { Criteria for participation } \\
\text { Core principle } 9\end{array}$ & $\begin{array}{l}\text { SAMA should issue a risk-based access policy and disclose its criteria } \\
\text { for fair and open access to SARIE by financial institutions. In this } \\
\text { context, possible access by nonbank financial institutions to SAMA } \\
\text { settlement systems should be discussed. }\end{array}$ \\
\hline
\end{tabular}




\begin{tabular}{|c|c|}
\hline Reference principle & Recommended actions \\
\hline $\begin{array}{l}\text { Governance of the payment system } \\
\text { Core principle } 10\end{array}$ & \\
\hline $\begin{array}{l}\text { Central Bank responsibilities in applying the } \\
\text { CPs } \\
\text { Central Bank responsibility } A B, C \text { and } D\end{array}$ & $\begin{array}{l}\text { SAMA's role in the payment system might be further clarified in an } \\
\text { upcoming ministerial decree. In addition, payment system oversight } \\
\text { could be also covered by the Payment System Law discussed under CP } 1 . \\
\text { SAMA should clarify in detail its policy stance in payment system } \\
\text { oversight in a publicly available document, which would expand on the } \\
\text { scope of its actions and its plans to achieve its public policy objectives in } \\
\text { payment system matters. } \\
\text { SAMA should accelerate the process of creating a full-fledged oversight } \\
\text { unit. Consideration should be given to where to place the new unit within } \\
\text { SAMA in order to enhance the visibility of the payment system oversight } \\
\text { function both internally and externally. } \\
\text { SAMA and the CMA are encouraged to finalize their MOU and include } \\
\text { specific references to the areas of joint interaction in the payments and } \\
\text { settlements space. Structured cooperation could take the form of joint } \\
\text { technical working groups of a permanent nature. SAMA could also } \\
\text { prepare memoranda of agreement among different departments with a } \\
\text { stake in the payments field. } \\
\text { An NPS Council/Committee could be constituted as a consultative and } \\
\text { cooperative body comprising representatives from relevant stakeholders } \\
\text { to provide an umbrella for the many existing technical committees and } \\
\text { enhance the visibility of the topic with the media and society as a whole. }\end{array}$ \\
\hline
\end{tabular}

\section{Considerations for Other Payment and Securities Settlement Systems}

\section{The main consideration for check clearing, SPAN, and SADAD is that settlement} risk management for retail payment systems might be reconsidered. All retail payment systems settle in SARIE. The individual systems send the final multilateral net clearing positions to SARIE, which aggregates them all and performs a consolidated final net settlement. While there are various liquidity optimization and liquidity support mechanisms available in SARIE, in the event of a credit problem encountered by a participant, liquidity support mechanisms might not be available, as all of them need good quality collateral. In the absence of credit by SAMA, the only recourse in such a case would be to unwind. However, given that the individual systems clearing positions are further netted against the clearing positions of all the other systems, unwinding would be extremely complicated and would raise a number of issues, most importantly the order and priority of the unwinds. A comprehensive risk management framework, perhaps combining net-debit limits in individual systems with a consolidated settlement guarantee fund, could be studied in order to mitigate these risks.

\section{Securities settlement systems work safely and efficiently, although some} improvements are envisaged. A detailed assessment of SSS with the CPSS-IOSCO recommendations for SSS was not within the scope of the FSAP Update. The CMA, 
however, provided a self-assessment of corporate securities based on the recommendations. The legal framework could be improved by the formal inclusion in the law of the concept of netting. Also, the segregation of client money and client assets, which is currently covered by the authorized persons regulation, could be included in the law. Equities transactions are settled on $\mathrm{T}+0$, with the cash leg occurring at the end of the day and the transfer of securities being executed immediately after trade confirmation. Risks in the settlement process are mitigated by the existence of caps and other controls. However, the CMA, Tadawul, and SAMA should accelerate their plans to move towards intra-day settlement based on DVP. Fair and open access to the settlement infrastructure by broker/dealers, in particular those that do not belong to a bank, should be discussed in the context of this reform. Furthermore, the government securities registry might be further integrated through appropriate interfaces with SARIE to facilitate collateralization in the RTGS system, as well as settlement of secondary market transactions.

\section{Authorities' Response}

19. The authorities have considered the findings of the detailed assessment. In response to SAMA's initial comments, the assessor:

- acknowledged the high level of standardization reached by the Saudi financial market;

- highlighted that the BCL provides SAMA with a legal framework for payment systems;

- recognized that the level of risk in securities settlement is mitigated by the fact that short-selling is not allowed and stocks are prefunded.

20. Other comments were addressed by the assessor, but not endorsed:

- according to SAMA, there is no compelling reason to expand the membership of the SARIE system;

- SAMA did not share the assessor's opinion that the current oversight regulation is not sufficiently detailed for the overseer to fully exert its power; SAMA also did not endorse the recommendation that a specific oversight unit should be created;

- SAMA stressed that although they are always looking for opportunities for improvement, they believe the current framework to be the most appropriate for the Saudi market. 